\title{
Marine Recreational Fishing in Portugal: Current Knowledge, Challenges, and Future Perspectives
}

Hugo Diogo, Pedro Veiga, Cristina Pita, Alina Sousa, David Lima, João Gil Pereira, Jorge M. S. Gonçalves, Karim Erzini \& Mafalda Rangel

To cite this article: Hugo Diogo, Pedro Veiga, Cristina Pita, Alina Sousa, David Lima, João Gil Pereira, Jorge M. S. Gonçalves, Karim Erzini \& Mafalda Rangel (2020) Marine Recreational Fishing in Portugal: Current Knowledge, Challenges, and Future Perspectives, Reviews in Fisheries Science \& Aquaculture, 28:4, 536-560, DOI: 10.1080/23308249.2020.1777083

To link to this article: https://doi.org/10.1080/23308249.2020.1777083

册Published online: 23 Jun 2020.

Submit your article to this journal

Џll Article views: 253

Q View related articles $\longleftarrow$

View Crossmark data $־$ 


\title{
Marine Recreational Fishing in Portugal: Current Knowledge, Challenges, and Future Perspectives
}

\author{
Hugo Diogo ${ }^{a, b}$ (D), Pedro Veigac, Cristina Pita ${ }^{\mathrm{d}}$, Alina Sousa ${ }^{\mathrm{e}}$, David Lima ${ }^{\mathrm{e}}$, João Gil Pereira ${ }^{\mathrm{a}}$, Jorge M. S. \\ Gonçalves ${ }^{c}$, Karim Erzini ${ }^{c}$, and Mafalda Rangel ${ }^{c}$

\begin{abstract}
a Okeanos - R\&D Centre, University of the Azores, Horta, Portugal; ${ }^{b}$ Direção de Serviços de Recursos, Frota Pesqueira e Aquicultura Direção Regional Das Pescas, Rua Cônsul Dabney - Colónia Alemã, Horta, Portugal; 'CCentre of Marine Sciences (CCMAR), University of Algarve, Faro, Portugal; ${ }^{d}$ CESAM - Centre for Environmental and Marine Studies, Department of Environment and Planning, University of Aveiro, Aveiro, Portugal; ${ }^{~}$ MARE - Marine and Environmental Sciences Centre, Polytechnic Institute of Leiria, Peniche, Portugal
\end{abstract}

\begin{abstract}
Marine recreational fishing (MRF) in Portugal is a traditional leisure activity with considerable importance for coastal populations. In the absence of available information from the national data collection framework, this article aims to review the existing information on MRF across the country. MRF was an open access fishery until recently, but with rising evidence of overexploitation of coastal resources, a precautionary approach was imposed topdown, without consulting recreational fishers. In Portugal, the MRF participation rate is comparable to the European average (2\%). The most important fishing mode (according to the official issued licenses) is shore angling. Mainland Portugal marine recreational catches ( $0.8 \%$ of total commercial landings) are likely underestimated, while the estimate for the Azores (6\% of total commercial landings) is probably closer to the national reality. The Portuguese MRF sector faces several challenges, including: (1) the need for a definition of a national data collection framework; (2) the inclusion of MRF harvest estimates in stock assessments for key captured species; (3) management approaches which also take into account the ecosystem approach to fisheries and any potential effects of climate change; (4) additional research on post-release mortalities for the most important MRF species; and (5) a stronger involvement of all stakeholders in the decision-making process of MRF. The latter would be critical to improve the adequacy of regulations to the MRF reality, mitigate conflicts with other sectors (e.g., commercial fishing), and potentially increase fishers compliance.
\end{abstract}

\section{KEYWORDS}

Recreational fisheries; angling; spearfishing; fisheries management; climate change

\section{Introduction}

Portugal has an extensive coastline and a tradition of exploiting marine resources that goes back to the first human settlements in the region (Bicho and Haws 2008). Marine recreational fishing (MRF) has always been a popular activity in Portugal and it is estimated that it currently involves between 170 and 200 thousand participants yearly (DGRM 2017; Hyder et al. 2017). As in most places, the main distinctive feature between recreational and small-scale commercial fishing in Portugal is the interdiction of selling the catch; but there are other differences such as the gears allowed, licensing schemes, and catch and effort restrictions (Pawson et al. 2008; Veiga et al. 2013). For legal and statistical purposes, there are three main categories of recreational fishing in the country: (1) recreational, conducted purely for leisure purposes; (2) sport fishing, conducted as part of an organized competition; and (3) angling tourism (or charter boat fishing) (DGRM 2016). There are also four marine recreational fisheries (MRF) modes regulated and with mandatory dedicated fishing licenses (shore angling/ hand harvesting, boat angling, and spearfishing). MRF takes place along all the Portuguese coast, from the intertidal zone to the shelf-break and beyond (when targeting large pelagic and highly migratory species), targeting a considerable number of marine species (Rangel and Erzini 2007; Veiga et al. 2010; Diogo and Pereira 2014).

In recent years, MRF has been subject to growing attention in European waters in terms of research and management initiatives (Ferter et al. 2013; Hyder et al. 2017). Nevertheless, and despite the 
legal requirements of European Union (EU) legislation on estimates of recreational catches for some species since 2009, recreational fisheries in many EU countries have not yet been subject to national-scale surveys, or are at an early stage as is the case of Portugal. In the absence of national data collection programs, it is important to compile all existing knowledge, especially when some heterogeneity is likely to exist on target species, catches, effort and socioeconomic features of the different fishing modes and/or for the different regions in the country (Gupta et al. 2015; Freire et al. 2016).

This article reviews and summarizes all available information on several aspects of Portuguese marine recreational fisheries, mainly in terms of ecological impacts, socio-economic importance, and evolution of the legal framework. Based on the main findings and patterns, recommendations for future research and management will be provided. The scope of this review is restricted to information collected on recreational fishing for the four main fishing modes (i.e., hand harvesting, shore angling, boat angling, and spearfishing), published in some form (i.e., including gray literature) and publicly available as of October 2018.

\section{Methodology}

Scientific information on Portuguese marine recreational fisheries was compiled through an exhaustive bibliographic search. Documents consulted included peer-reviewed papers, theses, research reports, and governmental related documents (reports, statistics, or other type of official documents). Published information was selected using Scopus (https://www.elsevier. com/solutions/scopus/) and RCAAP (https://www. rcaap.pt/) databases. A sensitive "rapid" systematic search strategy was employed combining Portuguese and English terms such as "recreational fisheries," "recreation," "spear," "sport," "boat" or "angler," "marine," "fishers," and synonyms. Titles and abstracts were screened to identify studies potentially eligible for inclusion. A subsequent screening process was undertaken for any relevant documentation not detected during the first search process. References in all relevant literature were screened for additional publications about MRF surveys in Portugal as suggested by Pita et al. (2011). The criteria for inclusion in the review were restricted to the following: (1) the document included Portuguese surveys on MRF and (2) the document reported data on Portuguese MRF (e.g., participation, catch and effort, socioeconomic data). Gray literature was selected using Google and Google Scholar online databases in Portuguese; the first 150 hits were evaluated. Gray literature for which full texts were not publicly available were not included in this review. Information was extracted, when possible, at regional level using Portuguese NUTS II areas as defined for statistical purposes (north, center, Lisbon Metropolitan Area, Algarve, Alentejo, Azores and Madeira archipelagos) and consisted of: (1) participation rates (estimated from official information on issued MRF licenses); (2) gears and fishing methods used; (3) main target and captured species; (4) catch rates; (5) fishing effort; (6) total estimated catches, main shared resources (among the different recreational fishing modes and also with commercial fisheries); and (7) socio-economic features (e.g., angler demographics, expenditures).

Other important topics also covered and discussed in the manuscript have included the legal framework for MRF in Portugal, other potential ecological impacts of MRF in Portugal, and management of MRF within Marine Protected Areas (MPA).

\section{Management of the marine recreational fishing activity in Portugal}

Marine recreational fishing in Portugal was an open access activity until 2005, without restrictions of any kind (Rangel and Erzini 2007; Veiga et al. 2013). The first record of a legal framework for MRF is from Decree $₫ 41444 / 1957$ (Figure 1). According to this regulation, recreational fishing was broadly defined as any fishing activity conducted by "amateur" fishers, practicing hook and line or underwater spearfishing, both from shore or boat, and without commercial purposes (i.e., ban on the sale of fish). From 1957 to the early 2000s, the MRF regulation was subject to several revisions and adjustments, but with no clear evidence that the anticipated measures were being effectively implemented or enforced. Effective measures to restrict MRF catch and effort were only formally put in place in 2006 through Portaria $\$$ 868/ 2006, which included restrictions such as daily bag limits, fishing licenses, prohibited species, spatial and temporal restrictions, minimum landing sizes-MLS (same to those applied for commercial fishing), as well as anticipated measures for future monitoring of the activity. From 2006 to 2014, the regulations were subject to several amendments. Portaria $\$ 14 / 2014$, the latest issued MRF regulation for mainland Portugal, includes the most up to date regulations in 


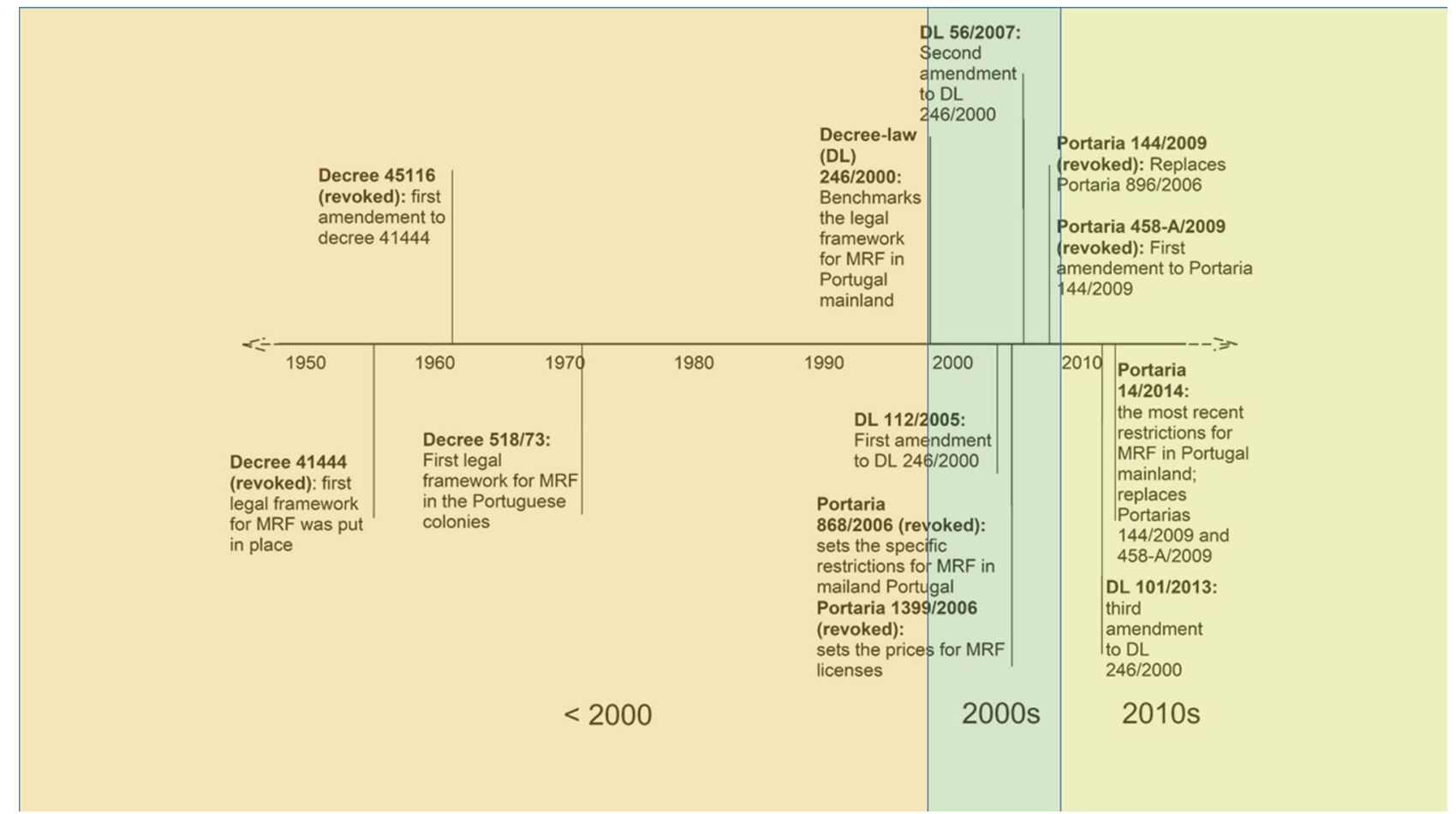

Figure 1. Timeline of the regulatory framework on marine recreational fishing (MRF) in Portugal mainland. Specific regulations on MRF in MPA and technical fisheries management measures that regulate species (e.g., minimum landing sizes and seasonal closures) are not included.

place for the activity (both at the local and national scales).

For the Azores and Madeira autonomous regions, the first regional regulations dedicated to MRF only considered spearfishing. These were issued in the mid-1980s in the Azores and a decade later (1995) in Madeira (Appendix Figures A1 and A2). Restrictions included daily catch limits (different for fish and specific crustaceans), prohibited species for specific fishing modes (e.g., dusky grouper, Epinephelus marginatus for spearfishing), mandatory fishing licenses, restrictions on allowed equipment, and the mandatory need to comply with existing or upcoming minimum landing sizes, and temporal and spatial restrictions for specific areas or species. More comprehensive regulations-covering all MRF modes and including measures to control user access and catch (e.g., fishing licenses, daily bag limits, temporal and spatial restrictions) - were only issued in 2007 in the Azores (Regional Legislative Decree $\$ 9 / 2007 / A$ ), and in 2016 in Madeira (Regional Legislative Decree $\$ 19$ / 2016/M)

Despite some differences in the timing of the implementation of regulations, and in terms of species landed, both the definition of MRF and the regulations are very similar across mainland Portugal, Madeira and the Azores (Appendix Table A1).

Available information about the effects of the MRF regulations in place shows that most shore anglers and spearfishers from mainland Portugal disagreed with the restrictions introduced in 2006 (through Portaria $₫ 868 / 2006$ ) (Veiga et al. 2013; Assis et al. 2018). In both studies, shore anglers and spearfishers believed that regulations are mainly unfounded, inadequate and unfair for the MRF activity. These findings may have important implications, as the lack of acceptance of MRF regulations can potentially result in increased noncompliance (Hauck et al. 2002; Veiga et al. 2013).

\section{Research on marine recreational fishing and data availability}

Research on MRF in Portugal is relatively recent, and available data is still limited to a few studies. The literature review revealed fifteen published studies dedicated to MRF since the mid-1990s. Most of these studies were based on on-site surveys via roving creel or access point surveys (Table 1). Two studies applied a complementary aerial-roving creel survey for 
REVIEWS IN FISHERIES SCIENCE \& AQUACULTURE -539

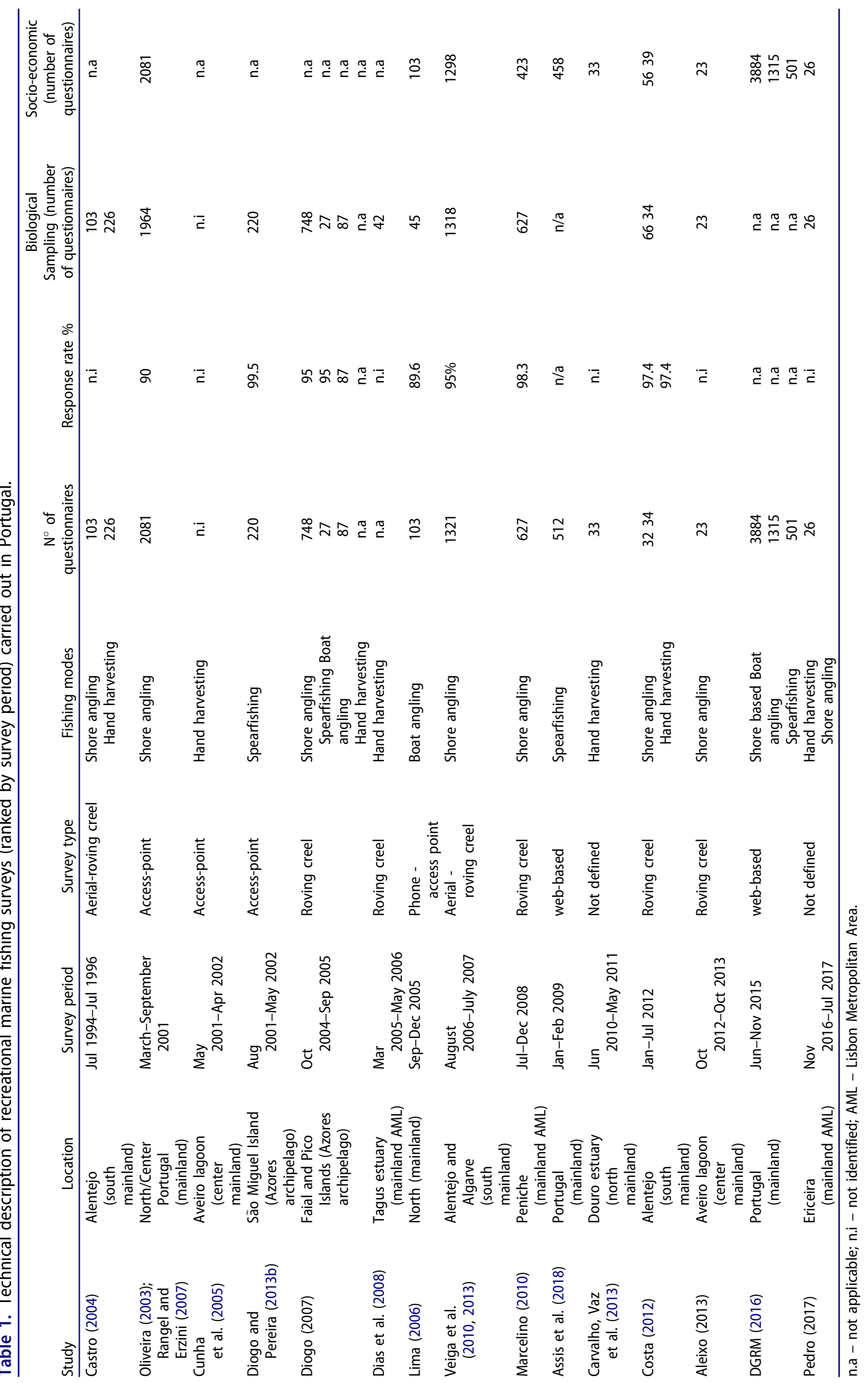


inshore marine recreational fisheries (i.e., Castro 2004; Veiga et al. 2010) and another used a phone-rovingcreel survey for recreational boats (Lima 2006). The first assessment of MRF at the national level focused on spearfishing only and was carried out by Assis et al. (2018) using a web-based survey. More recently, the Portuguese General Directorate on Natural Resources, Safety and Maritime Affairs (DGRM 2016), carried out a web-based survey for all MRF activities, for all mainland Portugal. Shore angling and hand harvesting are the best studied MRF modes in Portugal with nine surveys, followed by spearfishing (four) and boat angling (three) (Table 1). The Azores archipelago, and the south mainland (Algarve and Alentejo) were the regions with most surveys carried out, while the Madeira archipelago is the only region where no data on MRF surveys have been published so far (Table 1).

The Portuguese MRF studies are, somehow, limited in time and space, generally highly descriptive, with local or regional catch and effort estimates, but often with no associated errors for catch and effort calculations (Marcelino 2010; Santos 2014) or even for the economic value of the fishery (Santos 2014). Complementary methods to access adjustments of catch or effort data have not yet been used in Portugal, which is critical for the implementation of future national-level MRF surveys. The design of these national surveys will encounter many challenges related to the extension of the Portuguese coast, the territory dispersion (Archipelagos of Madeira and Azores, with eleven inhabited islands), the different fisheries management agencies, the bureaucratic difficulties for obtaining precise data on licensed fishers, and even with the political willingness to accomplish this task.

Portugal is however on the verge of changing paradigm. Large scale pilot studies were conducted in the meantime for Portuguese mainland, Azores and Madeira, as part of the DCF working plan 2017-2019. Nevertheless, to date, no results were made available to the scientific community.

\section{Characterization of the marine recreational fishing activity in Portugal}

\subsection{Participation in marine recreational fishing}

According to the number of emitted licenses, the total of participants in MRF in Portugal ranges between 170,000 and 200,000 individuals (DGRM 2017). This value represents roughly around $2 \%$ of the Portuguese population, and is similar to the overall Spanish participation rate in MRF (2\%) (Gordoa et al. 2019) and also to the European average (1.6\%). Nevertheless, the value is low when compared with some northern European countries where, in general, over $30 \%$ of the population is engaged in recreational fisheries (e.g., Iceland, Norway) (Hyder et al. 2017). According to the MRF licenses data, the most popular Portuguese mainland fishing mode is shore angling (68\% of the issued fishing licenses from 2007 up to 2016), followed by boat angling and spearfishing $(24 \%$ and $8 \%$, for the same period) (Appendix Table A2). In terms of hand harvesting, the licensing scheme is different for mainland Portugal and the Archipelagos. For the Azores and Madeira no license is required for hand harvesting, while in the mainland a license is only needed when using gear in the hand harvesting. In any case, this is deemed an important and relatively popular recreational activity across the country; according to available estimates, hand harvesting represents around $10 \%$ of the shore-based recreational activities (Diogo 2003, 2007; Marcelino 2010). An improvement of the Portuguese license system, specific to this activity, could reveal the real importance of this fishing mode.

\subsection{Demographic characteristics of recreational fishers}

The typical Portuguese marine recreational fisher is a male in his forties (Rangel and Erzini 2007; Veiga et al. 2010; Diogo and Pereira 2013a; DGRM 2016), employed, with a high-school education level (on average 10-12 years of formal education) (DGRM 2016). Spearfishers tend to be younger than other fishers, probably due to the greater physical demands of this activity (Diogo and Pereira 2013b, 2014; Assis et al. 2018). Shore anglers generally present lower educational level compared to spearfishers and boat anglers (Table 2). Boat anglers have generally higher incomes than spearfishers and shore anglers (Lima 2006; Rangel and Erzini 2007; Assis et al. 2018), which seems consistent with the higher costs of this fishing mode.

Most marine recreational fishers have more than 10 years of fishing experience (55\%; DGRM 2016), and go fishing between 11 and 60 days per year, although this varies according to the MRF mode (Rangel and Erzini 2007; Diogo and Pereira 2013b, 2014; DGRM 2016). The vast majority live near the coastline $(84 \%<20 \mathrm{~km}$ away; DGRM 2016), as is the case with the majority of the Portuguese population 
Table 2. Demographic profile of recreational fishers from the different marine recreational fishing (MRF) surveys in Portugal.

\begin{tabular}{|c|c|c|c|c|c|}
\hline Fishing mode & Study & Region & Sex & Age (years) & Most common education levels \\
\hline Shore angling & Oliveira (2003) & north/center & $99 \%$ Males & 40 & Primary education (38.9\%) \\
\hline Shore angling & Veiga et al. (2010) & Algarve/Alentejo & $99 \%$ Males & 48 & Lower secondary education (56.0\%) \\
\hline Shore angling & Marcelino (2010) & center & $98 \%$ Males & $41-64$ & Primary education (36.9\%) \\
\hline Shore angling & Diogo and Pereira (2014) & Azores & 93\% Males & 44.4 & n.a. \\
\hline Boat angling & Diogo and Pereira (2013a) & Azores & $100 \%$ Males & 45.1 & n.a. \\
\hline Boat angling & Lima (2006) & North & $96 \%$ Males & 46 & Upper secondary education ( $29.1 \%$ \\
\hline Spearfishing & Diogo and Pereira (2013b) & Azores & $100 \%$ Males & 27 & n.a. \\
\hline Spearfishing & Assis et al. (2018) & Portugal & n.a. & 33 & Lower secondary education (44.3\%) \\
\hline All fishing modes & DGRM (2016) & Portugal mainland & $98 \%$ Males & $25-45$ & Upper secondary education (42\%) \\
\hline
\end{tabular}

Age is given as the mean or the main age class. Most common educational levels (Primary education - up to 4 years of formal education; Lower secondary educational - up to 9 years of formal education; Upper secondary education - up to 12 years of formal education).

n.a. - not available.

(Deville et al. 2014). Information and estimates on the overall economic contribution (direct and indirect) of recreational fishing in Portugal are still limited. Even though, a recent study by Hyder et al. (2017), using available data, estimated that direct expenses (e.g., in bait, fuel, fishing gear) in MRF in Portugal represented around 139 million euros annually.

\subsection{Catch composition}

Portugal is located in a biogeographical transitional zone between temperate and subtropical waters with a meridionally orientated coast particularly appropriate for the observation of latitudinal patterns (Briggs 1974; Vinagre et al. 2010). A higher number of taxa is recorded for the south of mainland Portugal and the Azores islands, and lower diversity is reported in the north and center regions of mainland Portugal (Table 3; Appendix Table A3). In part, these differences can be associated with the higher diversity of the Sparidae and Labridae families, groups typically targeted and captured by recreational fishers in southern Europe (Morales-Nin et al. 2005; Lloret and Font 2013), that have greater biogeographic affinity to subtropical regions (Vinagre et al. 2010; Froese and Pauly 2019). Similar trends are expected for other MRF modes.

In terms of catch information by fishing mode and region, there are some differences in the main captured and target species. For shore angling, the most captured species is the white seabream (Diplodus sargus) in south mainland and in the Azores, and the European seabass (Dicentrarchus labrax) in northern mainland. Studies on boat angling and spearfishing in Portugal are scarce, and thus it is highly likely that the diversity of catches, and contribution to global catches from both fishing mode in Portugal are higher than registered (Appendix Tables A3 and A4).

In the case of boat angling, the blackspot seabream (Pagellus bogaraveo) was the second most captured species in the Azores and the main target species in mainland north, despite the low number of reported catches which are probably due to the current low abundance of the species (Lima 2006; Diogo and Pereira 2013b; ICES 2018). Nevertheless, in the northern region the most captured species were Atlantic horse mackerel (Trachurus trachurus), pouting (Tripsoterus luscus) and Atlantic chub mackerel (Scomber colias) (Lima 2006), which is in line with the findings of Gomes et al. (2001) and Sousa et al. (2005). Surveys with catch composition information on boat angling in southern areas of mainland Portugal are inexistent. Nevertheless, it is likely that the meridional trends detected by Gomes et al. (2001) in terms of species abundance and distribution-with a northern shelf assemblage dominated by Atlantic mackerel (Scomber scombrus) and pouting (Trisopterus spp.) and the southern shelf assemblage dominated by Sparids-are also reflected in the regional differences for the catch composition of this fishing mode.

For spearfishing, the research of Assis et al. (2018) highlighted the main target species in mainland Portugal as D. labrax, D. sargus, common octopus (Octopus vulgaris), red porgy (Pagrus pagrus), gilthead seabream (Sparus aurata), European conger (Conger conger), while, amberjacks (Seriola spp.) were reported as the main target species by Madeira and Azores spearfishers (Table 3, Appendix Table A5; Assis et al. 2018).

According to the available information, hand harvesting in Portugal is a popular activity in rocky intertidal areas (Castro 2004; Rius and Cabral 2004; Diogo et al. 2016). Some of the main target species in the rocky shores of the south (Alentejo) are: common octopus (Octopus vulgaris), stalked barnacle (Pollicipes pollicipes), Mediterranean mussel (Mytilus galloprovincialis), and several species of crabs, limpets, sea urchins, top shell snails and others (Castro 2004; see Table 4). Despite some differences of intertidal species assemblages between northern and center/southern regions (Boaventura et al. 2002), the species reported by Castro (2004) probably represent the most 
Table 3. List of the top five captured species (by weight) by marine recreational fishing in Portuguese waters, per survey/region.

\begin{tabular}{|c|c|c|c|c|c|c|c|}
\hline Fishing mode & Common name & Species & North & Center & Algarve/Alentejo & Azores & Source of information \\
\hline \multirow[t]{11}{*}{ Shore angling } & Atherina & $\begin{array}{l}\text { Atherina } \\
\quad \text { presbyter }\end{array}$ & 5 & $\mathrm{x}$ & $x$ & $\varnothing$ & $\begin{array}{l}\text { Mainland north: Rangel } \\
\text { and Erzini (2007); }\end{array}$ \\
\hline & Gray triggerfish & Balistes capriscus & $x$ & 2 & $x$ & $x$ & Mainland center: \\
\hline & Thicklip gray mullet & Chelon labrosus & $\mathrm{X}$ & $\mathrm{X}$ & 2 & 3 & Marcelino (2010); \\
\hline & European conger & Conger conger & 4 & $\varnothing$ & $\varnothing$ & $\mathrm{x}$ & Mainland Algarve and \\
\hline & European sea bass & $\begin{array}{l}\text { Dicentrarchus } \\
\quad \text { labrax }\end{array}$ & 2 & $\mathrm{x}$ & $x$ & $\varnothing$ & $\begin{array}{l}\text { Alentejo: Veiga et al. } \\
\text { (2010); Azores: Diogo }\end{array}$ \\
\hline & White seabream & Diplodus sargus & 3 & 4 & 1 & 1 & and Pereira (2014) \\
\hline & $\begin{array}{l}\text { Common two- } \\
\text { banded seabream }\end{array}$ & Diplodus vulgaris & $\mathrm{x}$ & 3 & 3 & $\mathrm{x}$ & \\
\hline & & Mugillidae & 1 & $\mathrm{x}$ & $\varnothing$ & $\varnothing$ & \\
\hline & Salema & Sarpa salpa & $\mathrm{X}$ & 4 & 4 & 5 & \\
\hline & Atlantic chub mackerel & Scomber colias & $\mathrm{x}$ & 1 & 5 & 4 & \\
\hline & Parrot fish & $\begin{array}{l}\text { Sparisoma } \\
\text { cretense }\end{array}$ & $\varnothing$ & $\varnothing$ & $\varnothing$ & 2 & \\
\hline \multirow[t]{9}{*}{ Spearfishing } & No common name & $\begin{array}{r}\text { Symphodus } \\
\text { caerulius }\end{array}$ & n.s & n.s & n.s & 3 & $\begin{array}{l}\text { Azores: Diogo and } \\
\text { Pereira (2013a) }\end{array}$ \\
\hline & Thicklip gray mullet & Chelon labrosus & n.s & n.s & n.s & 5 & \\
\hline & European sea bass & $\begin{array}{l}\text { Dicentrarchus } \\
\quad \text { labrax }\end{array}$ & n.s & n.s & n.s & $\varnothing$ & \\
\hline & $\begin{array}{l}\text { Common two- } \\
\text { banded seabream }\end{array}$ & Diplodus vulgaris & n.s & n.s & n.s & $\varnothing$ & \\
\hline & Common octopus & Octopus vulgaris & n.s & n.s & n.s & 1 & \\
\hline & & Pagrus spp. & n.s & n.s & n.s & $\varnothing$ & \\
\hline & Longfin yellowtail & Seriola rivoliana & n.s & n.s & n.s & 4 & \\
\hline & Parrot fish & $\begin{array}{l}\text { Sparisoma } \\
\text { cretense }\end{array}$ & n.s & n.s & n.s & 2 & \\
\hline & Gilthead seabream & Sparus aurata & n.s & n.s & n.s & $\varnothing$ & \\
\hline \multirow[t]{9}{*}{ Boat angling } & & Diplodus spp. & 4 & n.s & n.s & $\mathrm{x}$ & Mainland north: Lima \\
\hline & Dusky grouper & $\begin{array}{l}\text { Epinephelus } \\
\text { marginatus }\end{array}$ & $\varnothing$ & n.s & n.s & 5 & $\begin{array}{l}\text { (2006); Azores: Diogo and } \\
\text { Pereira (2013b) }\end{array}$ \\
\hline & Ballan wrasse & Labrus bergylta & g.l & n.s & n.s & 4 & \\
\hline & Axillary seabream & Pagellus acarne & 5 & n.s & n.s & $\mathrm{X}$ & \\
\hline & Blackspot seabream & $\begin{array}{l}\text { Pagellus } \\
\quad \text { bogaraveo }\end{array}$ & $\mathrm{x}$ & n.s & n.s & 2 & \\
\hline & Atlantic chub mackerel & Scomber colias & 3 & n.s & n.s & 3 & \\
\hline & Black comber & $\begin{array}{l}\text { Serranus } \\
\quad \text { atricauda }\end{array}$ & $\varnothing$ & n.s & n.s & 1 & \\
\hline & $\begin{array}{l}\text { Atlantic } \\
\text { horse mackerel }\end{array}$ & $\begin{array}{l}\text { Trachurus } \\
\text { trachurus }\end{array}$ & 1 & n.s & n.s & $\varnothing$ & \\
\hline & Pouting & Tripsoterus luscus & 2 & n.s & n.s & $\varnothing$ & \\
\hline
\end{tabular}

The most captured species are ranked from 1 (most captured) to 5 (5th most captured). X: Sampled species that do not belong to the top five. n.s: no survey. g.l: taxa identified to genera level. $\varnothing$ - Species not identified in the survey.

Note that the work of Rangel and Erzini (2007) covers a small part of Center region (until Aveiro), in addition of the North of the mainland.

commonly captured along the rocky shores of Portugal (Castro 2004). On the other hand, mobile substrates (especially mudflats of coastal lagoons and estuaries) are also sites of intensive harvesting, of several species of bivalves, gastropods, polychaetes, sipunculid worms, mud shrimps, and green crabs (see Table 4).

\subsection{Effort patterns}

Most recreational fishers, regardless of the fishing mode, prefer to fish on weekends and holidays (Castro 2004; Lima 2006; Diogo 2007; Marcelino 2010; Veiga et al. 2010). Moreover, late afternoons on weekdays are also popular for northern shore anglers (Rangel and Erzini 2007). Summer months (July to September) are usually the preferred time of the year for spearfishing, shore angling and boat angling (e.g.,
Lima 2006; Rangel and Erzini 2007; Diogo and Pereira 2013a). This is probably related to better weather conditions and due to the traditional Portuguese summer break from school and work. Spearfishing in particular is highly dependent on favorable sea conditions (e.g., good water visibility, low wave height) which are more common in the summer (Lima 2006; Diogo 2007; Rangel and Erzini 2007; Marcelino 2010; Veiga et al. 2010; Diogo and Pereira 2013a). Nevertheless, Veiga et al. (2010) found that catch rates, for shore anglers in southern Portugal were higher during autumn and winter, a period that coincides with the onshore spawning migration of $D$. sargus in this area.

In the case of hand harvesting, summer is the season with highest harvesting effort in the south (Alentejo) (Castro 2004). In spite of this, for some locations (e.g., Azores) (Diogo and Pereira 2014; 
Table 4. List of the most important target species of hand harvesting in rocky and mobile substrates in Portugal.

\begin{tabular}{|c|c|c|c|c|c|c|c|}
\hline \multicolumn{4}{|l|}{ Rocky shores } & \multicolumn{4}{|c|}{ Mobile substrates } \\
\hline Family & Common name & Species & References & Family & Common name & Species & References \\
\hline Lumbrineridae & "Tiagem" & Lumbrineris fragilis & Castro (2004) & Cardiidae & Common cockle & Cerastoderma edule & $\begin{array}{l}\text { Leitão and } \\
\quad \text { Gaspar (2007) }\end{array}$ \\
\hline Majidae & $\begin{array}{l}\text { European spider } \\
\quad \text { crab }\end{array}$ & Maja squinado & Castro (2004) & Donacidae & Bean clam & Donax spp. & Gaspar et al. (2002) \\
\hline Mytilidae & $\begin{array}{l}\text { Mediterranean } \\
\text { mussel }\end{array}$ & $\begin{array}{l}\text { Mytilus } \\
\quad \text { galloprovincialis }\end{array}$ & Castro (2004) & Eunicidae & Rock worm & Marphysa spp. & $\begin{array}{l}\text { Carvalho, Constantino } \\
\text { et al. (2013) }\end{array}$ \\
\hline Octopodidae & Common octopus & Octopus vulgaris & Castro (2004) & Muricidae & Purple dry murex & Bolinus brandaris & $\begin{array}{l}\text { Vasconcelos } \\
\text { et al. (2008) }\end{array}$ \\
\hline Parechinidae & Purple sea urchin & Paracentrotus lividus & Castro (2004) & Muricidae & Banded murex & Hexaplex trunculus & $\begin{array}{l}\text { Vasconcelos } \\
\text { et al. (2008) }\end{array}$ \\
\hline Patellidae & Limpet & Patella ulyssiponensis & Castro (2004) & Nereidae & $\begin{array}{l}\text { Common } \\
\quad \text { rag worm }\end{array}$ & Hediste diversicolor & $\begin{array}{l}\text { Carvalho, Vaz } \\
\text { et al. (2013) }\end{array}$ \\
\hline Patellidae & Limpet & Patella vulgata & Castro (2004) & Onuphidae & Polychaeta & $\begin{array}{l}\text { Diopatra } \\
\quad \text { neapolitana }\end{array}$ & $\begin{array}{l}\text { Cunha et al. (2005); } \\
\text { Costa et al. (2015) }\end{array}$ \\
\hline Patellidae & Limpet & Patella depressa & Castro (2004) & Pharidae & Razor clam & Ensis siliqua & $\begin{array}{l}\text { Constantino } \\
\text { et al. (2009) }\end{array}$ \\
\hline Pollicipedidae & Stalked barnacle & Pollicipes pollicipes & Castro (2004) & Portunidae & Green crab & Carcinus maenas & $\begin{array}{l}\text { Carvalho, Constantino } \\
\text { et al. (2013) }\end{array}$ \\
\hline Portunidae & Velvet crab & Necora puber & Castro (2004) & Semelidae & Burrowing & Scrobicularia plana & $\begin{array}{l}\text { Carvalho, Vaz } \\
\text { et al. (2013) }\end{array}$ \\
\hline Trochidae & Common top shell & Phorcus lineatus & Castro (2004) & Sipunculidae & Peanut worm & Sipunculus nudus & $\begin{array}{l}\text { Carvalho, Constantino } \\
\text { et al. (2013) }\end{array}$ \\
\hline Trochidae & Flat top shell & $\begin{array}{l}\text { Steromphala } \\
\text { umbilicalis }\end{array}$ & Castro (2004) & Upogebidae & Mud shrimp & Upogebia sp. & $\begin{array}{l}\text { Carvalho, Constantino } \\
\text { et al. (2013) }\end{array}$ \\
\hline Trochidae & Flat top shell & $\begin{array}{c}\text { Steromphala } \\
\text { pennanti }\end{array}$ & Castro (2004) & Veneridae & Carpet shell clam & $\begin{array}{l}\text { Ruditapes } \\
\text { decussatus }\end{array}$ & Cravo et al. (2012) \\
\hline
\end{tabular}

Diogo et al. 2016) or particular species (e.g., purple sea urchin, Paracentrotus lividus; limpet, Patella candei; M. galloprovincialis) (Castro 2004, Ferreira et al. 2013, Diogo et al. 2016), spring and winter (or specific time periods such as Easter) can also be important for this recreational activity. This can be related with seasonal abundances, traditional harvesting periods (such as religious holidays), or with the reproduction period of the resource (Castro 2004; Ferreira et al. 2013; Diogo et al. 2016).

\subsection{Catch and harvest estimates}

Catch rates and fishing effort are the key components for estimating total catch and harvest in recreational fishing surveys (Pollock et al. 1997). Catch rates in Portugal, as expected, tend to vary between areas and MRF modes. For example, shore angling shows an increasing gradient from north to south (Table 5), with the highest catch rates reported for south mainland and for the Azores (Table 5). With respect to fishing mode, catch rates for shore angling in Portugal are in general lower than that those reported for boat angling and spearfishing (Table 5), a phenomenon also found in other geographical areas (Meyer 2007; Lloret et al., 2008; Font and Lloret 2014). For hand harvesting, the available estimates in the literature are not comparable with other fishing modes. Though, Castro (2004) and Costa (2012) suggested that the harvest rates by weight per $\mathrm{km}$ of coastline are considerably higher than for shore angling. This may be related with a number of factors, but especially the type of species targeted by each fishing mode; while shore anglers target mobile fish with a passive gear (hook and line), hand harvesters actively seek and capture sessile organisms such as limpets, $P$. pollicipes, M. galloprovincialis or clams.

The estimation of total harvest (daily, monthly, annual) is the product of fishing effort and catch rates but unfortunately due to the absence of national surveys only estimates of total catch per fishing mode and specific regions in limited time periods exist. Nevertheless, some authors used the available data to estimate the total catch for larger regions. For example, in the Azores Pham et al. (2013) estimated a recreational harvest of around 600 tonnes (about 6\% of the commercial landings), with $96 \%$ of the recreational catch related to shore and boat angling. For the Portuguese mainland Leitão et al. (2014) estimated a mean annual MRF total catch of 1791 tonnes $(0.8 \%$ of commercial landings), based on MRF licenses, catch rates, effort and catch composition provided by Veiga et al. (2010). Nevertheless, this estimate may not fully reflect the Portuguese MRF situation, given 
Table 5. Catch rates per hour per angler in number and weight of different marine recreational fishing (MRF) modes at different locations of Portugal.

\begin{tabular}{lllc}
\hline MRF mode & \multicolumn{1}{c}{ Study } & \multicolumn{1}{c}{ Location } & CPUEn (fish angler $^{-1} \mathrm{~h}^{-1}$ ) \\
\hline Shore angling & Rangel and Erzini (2007) & North/Center & 0.5 \\
& Marcelino (2010) & Center & 0.5 \\
& Veiga et al. (2011) & Algarve/Alentejo & 0.08 \\
& Diogo and Pereira (2014) & Azores & 1.1 \\
Boat angling & Lima (2006) & North & 1.4 \\
& Diogo (2007) & Azores & 14.0 \\
Spearfishing & Diogo (2003); Diogo and Pereira (2013b) & Azores & 0.21 \\
& Diogo and Pereira (2014) & Azores & 3.7 \\
\hline
\end{tabular}

Note that the CPUE of boat angling is per boat instead of per angler.

the different fishing patterns for spearfishing and boat angling (generally higher catch rates, fishing effort more dependent on sea conditions, etc.). More research on boat angling, spearfishing and hand harvesting at the regional level is needed to provide better estimates of the total mainland MRF catches. Furthermore, the absence of studies in Madeira does not allow a national estimate of MRF catch for all Portugal.

\section{Release and harvest of undersized fish on MRF}

Recreational fisheries effort is generally concentrated in inshore areas, including lagoons and estuarine areas that are important nurseries of many fish species targeted by recreational and commercial fishers in Portugal (Santos and Nash 1995; Ribeiro et al. 2006; Vasconcelos et al. 2009; Vinagre et al. 2009; Aleixo 2013). For this reason, research on released and kept juveniles or undersized fishes is a key component for assessing the impact of MRF (Veiga et al. 2010; Pinho et al. 2014). In Portugal, the main reason reported by recreational fishers for releasing fish is the total size (Marcelino 2010; Veiga et al. 2010; Diogo and Pereira 2014), even though, species with no (or low) gastronomic value tend to have higher release rates as well (Veiga et al. 2010; Diogo and Pereira 2014). The reported releases in number for shore angling in southern mainland Portugal (Algarve and Alentejo) represented $23 \%$ of the total catch determined by Veiga et al. (2010). In Peniche (center region) and in the Azores islands the release rates were lower (10.4\% and 4.6\%; respectively) (Marcelino 2010; Diogo and Pereira 2014). With the current closed seasons in place for certain areas and important commercial species (e.g., seabreams) (Decree $\$ 115-\mathrm{A} / 2011$ ), higher release rates of these species are expected, regardless of size.

Analyzing the main target species, in southern Portugal mainland and in the Azores, D. sargus had a release rate of $18 \%$ and $4.8 \%$, respectively (Veiga et al.
2010; Diogo and Pereira 2014), while in Peniche, there are zero releases reported for the main target species S. colias (Marcelino 2010). Although fish size can be considered as a major reason for anglers to release (Veiga et al. 2010; Diogo and Pereira 2014), the retention of juvenile specimens is higher for particular species and regions. In Azores and Peniche for example, the retention of undersized fish was observed for a higher percentage of the captured species $(38 \%$ and 71\%; respectively) (Marcelino 2010; Diogo and Pereira 2014). In southern Portugal, despite the overall low percentage of undersized fish kept (11.5\%), for important commercial species such as D. labrax most (73\%) of the harvested fish is undersized (Veiga et al. 2010). The reasons for this behavior were associated with shore anglers disagreement regarding this regulation, or due to lack of awareness about the MLS in place, but also because this is a highly appreciated species (Veiga et al. 2010). Moreover, the lack of compliance with legislation by marine recreational fishers and lack of enforcement of rules and regulations is a well-known reality in Portugal, which needs to be reverted (Diogo et al. 2016).

In Portugal, as in other southern European countries, the main target species present a higher level of harvested juveniles and undersized fish, compared to northern European countries, Australia, USA or Canada (Ferter et al. 2013). These differences are probably related with consumption patterns, angling regulations and catch rates (Ferter et al. 2013). The impact of harvesting juveniles in MRF on fish stocks is important to analyze, especially for species with complex life-histories and already fully or overexploited. For example, in the Azores, P. bogaraveo is the most important commercial fishing resource, and despite being considered a deep-water species, the nursery grounds are located inshore, along the coastline where the species remains during the first year of life, when it is harvested by shore anglers and commercial fisheries alike. Even though, MLS is in place for P. bogaraveo since 2006, there is a special exception in place for recreational shore angling (Pinho 
et al. 2014). A stock-recruitment projection made for this species estimated that a total ban of harvesting juveniles would provide a long-term increase of $15 \%$ and $8 \%$ in spawning-stock biomass and catch, respectively, as well as a $13 \%$ increase in the value of landings (Pinho et al. 2014).

The enforcement of existing MLS regulations with positive effects on stock size will likely vary between species, due to factors such as the species life-history, stock status and current fishing mortality levels. Nevertheless, the analysis of Pinho et al. (2014) indicated that, at least for some species, the overall decrease of harvested juveniles and undersized fish would potentially contribute to an increase in the stock size in the long term. Besides specific regulations and increased enforcement to minimize harvesting of undersized fish educational programs have also been acknowledged as an important tool to shape values and attitudes, increase anglers awareness toward regulations (e.g., MLS), minimize the capture of unwanted species and sizes (through adapting gear and fishing practices), increase the release proportions of undersized fish, and promote better handling and release procedures (Veiga et al. 2011; Ferter et al. 2013; Veiga et al. 2013).

\section{Competition for shared resources between MRF and commercial fisheries}

Although the overall magnitude of recreational catches in relation to commercial landings is generally low, recreational harvests of some species and/or in some areas have been found to be substantial (Veiga et al. 2010; Pham et al. 2013; Diogo and Pereira 2013b, 2014; Leitão et al. 2014). For example, Veiga et al. (2010) estimated that, in southern Portugal, although overall shore angling catches corresponded to $0.8 \%$ of the commercial landings, for $D$. sargus recreational shore angling catches corresponded to $65 \%$ of the commercial landings $(39.4 \%$ of the total catch; Veiga et al. 2010). In contrast, $D$. sargus is not an important commercial species in the Azores, which might explain why the recreational catch accounts for $220 \%$ of the official commercial landing statistics (Pham et al. 2013). Some important Azorean coastal commercial species are also captured in large quantities by recreational fishing. For example, catches of blacktail comber, Serranus atricauda and parrot fish, Sparisoma cretense were estimated as corresponding to $85 \%$ and $60 \%$ of the commercial landings, respectively (Pham et al. 2013). In northern mainland Portugal, the magnitude of shore angling catch compared to the commercial sector seems much lower. Shore angling catches of D. labrax, for example, corresponded to only $5.8 \%$ of the local commercial landings, while $D$. sargus corresponded to $1.2 \%$ (Rangel and Erzini 2007). Nevertheless, the availability of official landings data for this region was limited at that time and new studies are needed to confirm these results.

In terms of boat angling, $25 \%$ of the catches in the Azores are from demersal/deep-water species, with some species, such as the Blackspot seabream ( $P$. bogaraveo) already considered under heavy fishing pressure, and with recovery plans in place (ICES 2018; EC. Reg. 2340/ 2002). Even though, boat angling only accounted for $3 \%$ of commercial landings for these species (Menezes et al. 2013; Pham et al. 2013; Diogo and Pereira 2013b). In northern mainland Portugal, the main target species is $P$. bogaraveo, but deep-water species are captured in lower quantities. The impact of boat angling on particular coastal species, especially from the Sparidae family, is likely considerable. More surveys and research on this activity are required in order to better evaluate its contribution to the overall Portuguese catches.

Hand harvesting catch estimates are limited, but the Portuguese General Directorate on Natural Resources, Safety and Maritime Affairs (DGRM) highlighted the importance of hand harvesting (DGRM 2017). Although the contribution of the recreational sector is not well-known, shellfish and stalked barnacle $(P$. pollicipes) harvesting are estimated to represent around $15 \%$ of the total Portuguese mainland MRF captures according to the DGRM on-line survey (DGRM 2016). Stalked barnacle (the most important intertidal commercial resource) landings have shown a declining trend, likely associated to both recreational and commercial harvesting (Cruz et al. 2015). The same pattern has been reported in the Azores for limpets (Patella aspera, $P$. candei), the main commercial intertidal species (Diogo et al. 2016). Annelids are another group of species usually indirectly impacted by the recreational fishing activity. According to Costa et al. (2015), approximately 100 tonnes year $^{-1}$ of polychaete worms are harvested for bait from Portuguese estuaries and coastal lagoons, with most of the harvesting undertaken by professionals who supply fishing tackle shops.

Even though, the available estimates reveal an important contribution of recreational fishing in terms of total catches in coastal areas and for certain resources, the overall impact of MRF catches on the stocks of harvested species at the national level is largely still unknown due to the limited dedicated research and data collection. 


\section{Vulnerable species}

Assessing recreational harvesting of important fish species is vital but does not depict the entire story of direct impacts of recreational fishing ( $\mathrm{McPhee}$ et al. 2002). The diversity of species captured by recreational fishing in Portugal is considerable, representing a great diversity of life histories. While some species are more resilient and can support relatively high levels of harvesting, others tend to decline even with low levels of exploitation (McPhee et al. 2002; Cheung et al. 2007). Some of the species captured by MRF that are of greatest concern to conservation in Portugal and currently categorized as threatened or vulnerable by IUCN (2018) are allis shad, Alosa alosa; barred hogfish, Bodianus scrofa; island grouper, Mycteroperca fusca; E. marginatus; bluefish, Pomatomus saltatrix and gray triggerfish, Balistes capriscus. Using a precautionary management approach, the harvest of species such as A. alosa, E. marginatus, European lobster, Homarus gammarus, spiny lobster, Palinurus elephas was prohibited for recreational fishing in mainland Portugal.

Though, there are other species potentially vulnerable to fishing for which the current management systems may be insufficient or inadequate to prevent overexploitation. Meager (Argyrosomus regius), D. labrax, M. fusca, white trevally (Pseudocaranx dentex) and longfin yellowtail (Seriola rivoliana) all characterized by slow growth, late maturation, lower reproductive potential, and limited habitat availability and may also be highly vulnerable to the current fishing pressure, and particular attention should be paid to them (Cheung et al. 2007; Veiga et al. 2010; Diogo and Pereira 2013a, 2013b). Also, some species tend to be more vulnerable in specific stages of their life cycle, especially those characterized by spawning aggregation events (Russel et al. 2012). In Portugal, inshore spawning aggregations are known for several species such as $D$. sargus, A. regius, and D. labrax (e.g., Prista et al. 2008; Veiga et al. 2010; Vinagre et al. 2012). Any assessments of fishing impacts and respective management measures should thus consider the relative vulnerability of these and other species to the various MRF modes. For example, while shore angling in the Azores accounts for a greater volume of fish and species than spearfishing, it tends to impact species with lower indexes of vulnerability to fishing (Diogo and Pereira 2014). The impact of spearfishing can be more pronounced on vulnerable species with life cycles confined to shallow waters that overlap with the operational depths of this activity (usually < $25 \mathrm{~m}$ depth; Diogo and Pereira 2013b). This impact can be magnified in areas of limited available habitats, such as in the volcanic islands of the Azores and Madeira, where the shelf is very narrow or absent (Diogo and Pereira 2013b). Marine recreational fisheries impacts are cumulative and concurrent, and besides spearfishing, boat angling also catches a number of vulnerable coastal species (e.g., groupers, blackspot seabream), and with higher depth ranges than spearfishing, diminishing the possibility of a depth refuge for some vulnerable coastal species targeted by both fishing modes (Diogo and Pereira 2013a, 2013b; Lindfield et al. 2014). Moreover, most of these vulnerable coastal species are also sought after and captured by the artisanal commercial fishing activity. This complexity can be addressed by improving the knowledge of the combined impact of commercial and MRF on the most vulnerable species, and by adapting the respective legislation with adequate precautionary and protection measures and proper enforcement.

\section{Ecological footprint of MRF}

The use of natural bait by anglers represents an additional impact of MRF in the ecosystems (McPhee et al. 2002), and the harvesting of some species to be used as bait causes a potential greater impact on ecosystems than that of the retained catches and discards alone. Much of the bait used by anglers is collected on rocky shores and sedimentary intertidal areas where a wide range of invertebrates (polychaetes, crustaceans, molluscs), and algae are harvested. Bait collection is a key factor for angling success; an example of this is the harvesting of algae Fucus spp. in spring, which is used to capture salema, Sarpa salpa (Castro 2004; Diogo and Pereira 2014). The ecological effects of algae harvesting has implications for intertidal communities (Addessi 1994). Also, rock-turning to catch marble crab, Pachygrapsus marmoratus (Diogo and Pereira 2013b; 2014), or polychaete worms (e.g., "tiagem"; Castro 2004) may reduce the densities and even change species composition of under-rock communities (Addessi 1994). Polychaete worms are highly targeted in mudflats of lagoons and estuaries (e.g., Hediste diversicolor, Diopatra neapolitana), and are some of the most popular baits in Portugal (Oliveira 2003; Cunha et al. 2005; Diogo 2007; Marcelino 2010; Aleixo 2013; Costa et al. 2015). Catches of live bait by recreational fishers are deemed considerable, based on the live bait trade and fishing tackle shops across the country (Cunha et al. 2005; Aleixo et al. 2014). Nevertheless, the high productivity of the estuarine systems is assumed to support high 
levels of harvesting impact (Carvalho, Vaz et al. 2013) and, in general, the impact of bait collection on the intertidal area seems more severe on rocky shores (Oliveira 2003; Marcelino 2010; Diogo and Pereira 2014).

It seems obvious fair to recognize that, in the context of research and fisheries management, bait collection impact has been historically overlooked as a part of the angling activity. Additionally, many shore anglers use non-indigenous live-bait species (i.e., polychaete worms), imported and commercialized in local stores. Previous cases in Portugal and elsewhere show that many of these species have generally high chances of establishment with potential negative consequences to native species and coastal ecosystems (Micael et al. 2016; Sá et al. 2017).

Other angling related impacts in the ecosystems have been also documented. For example, Rodríguez and Pham (2017) registered a high quantity of marine litter in traditional fishing grounds of recreational boat angling in the Azores. Similar patterns of pollution associated to recreational fishing were observed in several hotspots of shore angling across the country (Diogo 2003; Oliveira 2003), and elsewhere (e.g., Radomski et al. 2006; Lloret et al. 2014). Litter is recognized to lead to localized habitat alterations (Arlinghaus and Cooke 2009). Also, many kinds of birds and animals can become entangled in lost fishing lines and hooks, which can result in injury or death (Nemoz et al. 2004; Arlinghaus and Cooke 2009). Another relevant problem is lead pollution from lost fishing sinkers; Oliveira (2003) estimated that shore anglers from the north of Portugal lost approximately six tonnes of lead in one year. Spearfishing has been found to have a low indirect impact due to gear loss (Diogo and Pereira 2013b). Even so, the impact of this activity on fish that escape wounded from the harpoons, and on behavior of some fish species, is becoming a topic of increasing interest for research (Diogo and Pereira 2013b; Tran et al. 2016).

Marine recreational fishing can also impact local and even regional populations of other marine animals through trophic interactions (McPhee et al., 2002). For instance, the reduction of abundance of higher trophic levels in shallow waters is reflected in changes in the abundance and size structure of fish communities. More important is the potential to create a top-down ecosystem effect, generating ecological imbalance and changing the composition of natural communities (Dulvy et al. 2002; Lloret et al. 2008).

\section{MRF and MPA}

Marine protected areas (MPA) have emerged over the last decades as a key tool for fisheries management and conservation (Vandeperre et al. 2011; Pita et al. 2013). In Portugal, 52 MPA were implemented over the last three decades; these MPA currently cover $6.5 \%$ of the Portuguese EEZ, covering an area of $112364.9 \mathrm{~km}^{2}$ with $86 \%$ located in coastal areas (Batista and Cabral 2016). Despite the growing tendency of enlarging the MPA network in Portugal, only $9.6 \%$ of the Portuguese MPA have no-take areas and the average percentage of no-take areas within MPA ranges from extremely low, $2.2 \%$ in mainland Portugal, to high (76.0\%) in Madeira (Batista and Cabral 2016).

Marine protected areas in Portugal, as elsewhere, include a large variety of zoning and management schemes from single to multiple-zoning and from notake to multiple-use areas. The multiple-use areas within MPA present different level of restriction for MRF gears and/or modes because some are considered more damaging than others (Horta e Costa et al. 2016). Spearfishing within MPA is, in many cases, completely banned, while other MRF modes, such as shore angling and hand harvesting, tend to be allowed, restricted to residents or permitted in partially protected areas but limited to some days of the week (Inglês 2010; Sousa et al. 2013; Horta e Costa et al. 2014; Pereira et al. 2017).

The management discrepancy currently observed for the different MRF modes, and between recreational and commercial fishing (Fernández et al. 2016) tends to be controversial. Certain groups of fishers feel they are being discriminated against and are of the opinion that banning only a particular activity has little positive effects on the effective protection of main coastal fish stocks (Assis et al. 2018). The success of MPA requires a better integration of stakeholders (in this case recreational fishers) in the MPA decision-making process and better-informed recreational fishers, as the lack of knowledge about the regulations and absence of involvement of recreational fishers may result in lower compliance with rules and regulation overall (Veiga et al. 2013; Diogo et al. 2016). The success of MPA also requires more integration of science, with robust fisheries data, and the importance of MRF research has been highlighted recently in several studies that integrate MRF fishing effort in the process of designing and implementing marine reserve networks (Schmiing et al. 2014; Abecasis et al. 2015). In this context, mapping MRF fishing effort is a key component of the analysis along with different users' costs and benefits (i.e., spatial patterns of the abundance and reproductive potential of different species, vulnerability of fish to fishing, 
habitat type, algae biotopes, and other socio-economic costs and benefits (Schmiing et al. 2014; Abecasis et al. 2015).

\section{Climate change}

Temperate transition zones, such as the case of Portugal, are often recognized as hotspots of biodiversity, with species adapted to natural cyclic oceanographic fluctuations (Horta e Costa et al. 2014). The disruption of these natural cycles is already affecting shelf fish assemblages (Horta e Costa et al. 2014; Teixeira et al. 2014). Due to global warming, it is expected that cold-temperate affinity species targeted by the Portuguese MRF will tend to be scarcer in the future, while warm-temperate and tropical species will be more abundant and move north (Horta e Costa et al. 2014; Teixeira et al. 2014). This pattern is already being documented in artisanal Portuguese fisheries, where the decline of some traditional species is driving small-scale fisheries to start targeting different species using different gears, fishing grounds, and fishing tactics taking into account the market and the income, such as the increase in landing of gilthead seabream, S. aurata, axillary seabream (Pagellus acarne) and common dentex (Dentex dentex) (Teixeira et al. 2014). The same tendency is expected for MRF, in the absence of some traditionally targeted species, a shift to new species is expected, together with changes in catch composition, catch rates, operational methods and even fishing patterns.

\section{Global MRF situation and recommendations for marine recreational fishing in Portugal}

Despite FAO annual data requests for the inclusion of recreational catch data from national surveys these are still mostly unavailable in many developing countries, unlike developed countries as Australia (Henry and Lyle 2003) and Canada (Brownscombe et al. 2014), where such surveys are common and have been conducted for several decades. For this reason, global reconstruction of recreational catches are to certain point imprecise (Pauly and Zeller 2016). Even though, developing countries as Brazil and India are starting to realize the importance of implementing national level recreational fishing surveys, the available data on these countries is still time and space limited (Gupta et al. 2015; Freire et al. 2016).

Recreational fishing participation rates across the world presents a high variability since it is affected by several factors, such as socio-economic, geographic, and demographic status of the populations (CisnerosMontemayor and Sumaila 2010). According to Hyder et al. (2017) across industrialized countries, there is a positive relationship between recreational fishing participation rates and per capita gross domestic product (GDP). In fact, globally Africa and Asia present the lowest participation rates (Cisneros-Montemayor and Sumaila 2010), followed by Europe with a participation rate of $1.6 \%$ (Hyder et al. 2017) approximately half of USA (3.3\%; NMFS 2015; 2016). Nevertheless, in Europe, there are significant differences, with Iceland and Norway having high participation rates (> 30\%) while Germany has the lowest (0.2\%). Also, participation rates are higher in the Atlantic European coast than in Mediterranean coasts, revealing the participation rate variability and complexity within Europe (Hyder et al. 2017). The highest global participation rate in MRF occurs in Oceania with participation rates in New Zealand of $17.0 \%$ and Australia of 19.5\% (Henry and Lyle 2003; Wynne-Jones et al. 2014). Other factors that could account for the variability of participation rate relate to the apparent need for leisure and to the cultural importance of fish in particular countries, suggesting that effects of industrialization vary in importance across different countries (Arlinghaus et al. 2015). Though, independently of the participation rate, the average days fishing across Europe seem to be quite similar (5-10 days per fisher per year), which could indicate that despite the variability of target species and environments, between countries and within regions, the factors which can explain the time that fishers dedicate to MRF may have common elements (Hyder et al. 2017).

On the other hand, the biological and ecological impact of MRF cannot be overlooked since global catches could be $14 \%$ higher if recreational fishing is included in overall landings (Cooke and Cowx 2004). This is especially true for some species or locations where MRF can even exceed commercial landings (McPhee et al. 2002). Moreover, catch and released practices should be consider in MRF, especially because in some species the post-released mortalities are considerable high (Ferter et al. 2013). The inclusion of recreational fisheries in stock assessment is key for the proper management of several important stocks; however, there is still a deficiency of MRF time series data for many individual stocks in Europe and in many other regions of the world making inclusion of data in stock assessment a challenge (Hyder et al. 2017). 
Portugal is considered an industrialized country, however in terms of research on MRF it is still behind most of the developing countries which have a long tradition in this research field. Data collection and research on MRF in Portugal has been mostly confined to academic studies, scattered in space and time. Even though, data collection of recreational fishing is a European legislative requirement since 2002 (Council Regulation No. 1639/2001 of 25 July 2001). Still, Hyder et al. (2017) have noticed that only a few countries have followed this obligation (European Union Member-States are now obliged to develop national monitoring programs on recreational fishing for several species under the Data Collection Framework (DCF) (ICES 2010; Hyder et al. 2017) and this the compilation of the available Portuguese MRF research literature could provide some insights into the Portuguese MRF sector over the last 20 years, identifying the current challenges and knowledge gaps, providing, at the same time, recommendations for future research, needs for monitoring programs, and ways to improved management of the activity.

Relevant recommendations include:

- Implementation of regular mandatory MRF national data collection surveys to estimate fishing effort, catch and economic valuation of the activity. These surveys should contemplate complementary methods and data validation (National Research Council 2006), and consider the bias effects inherent to off-site methods (e.g., recall bias, nonresponse bias (National Research Council 2006)) and of on-site surveys (National Research Council 2006; Diogo and Pereira 2016; Diogo et al. 2017). National MRF monitoring framework could be supported (at least partially) by funding from recreational fishing licenses.

- Introduction of an important human dimension component in all future MRF surveys and evaluation of ecological impacts, such as the effect of MRF on species richness and identification of the most vulnerable species.

- Systematic monitoring of MRF at the national level must also act as an essential tool to understand trends in fishing pressure, participation and catches, and how these relate to factors like climate change.

- Better characterization and analysis of several fishing modes, such as boat angling and spearfishing needs to be addressed; in some regions, such as the Madeira archipelago, MRF still surveys need to be implemented.
- The Portuguese licensing system should change to improve available statistics. One important step would be the removal of the multimode fishing license, which results in over or under estimation of the real number of fishers per fishing mode. Additionally, researchers should have permission to access the registry (i.e., phone contact) of licensed recreational fishers in order to improve survey coverage and estimates. Also, licenses should be issued, once again, at a regional level (licenses changed from regional-NUTS II level-to national wide in the beginning of 2014), to allow the analysis of MRF impacts locally. A national standardization of the licensing scheme is also important, since the Azores and Madeira archipelagos do not have a license system for shore angling, and for boat angling the license scheme is also different from the one in place in the mainland.

- Data on post-release mortalities of important MRF species is still very limited for Portugal, only available for three species, and for shore angling specifically (Veiga et al. 2011). It is extremely important to evaluate the potential post-release mortalities imposed by MRF of other important species.

- The recognition of the importance of MRF, coupled with a strong MRF research are key components to change from a top-down management approach toward co-management involving all stakeholders. In this process it is necessary to strengthen the role of MRF associations (Pita et al. 2017). The recreational fishers must be more involved in the decision-making process in order to reduce the conflicts between artisanal and MRF. More and adequate research and estimates of the socio-economic importance of MRF are also needed, in order to better understand the socioeconomic benefits of this sector. Illegal unreported and unregulated fishing under the umbrella of MRF has been registered (Diogo and Pereira 2013a; Diogo et al. 2016) or recognized based on anecdotal evidence (Rangel and Erzini 2007; Veiga et al. 2010) and is considered a problem in some areas. Illegal unreported and unregulated fishing has been one of the triggers for increased competition and conflict between the recreational the commercial fishing sectors and should thus be properly assessed and addressed.

- The current available knowledge on the species biology, population dynamics, fisheries exploitation patterns, and on the multiple resource users, needs to be integrated in the technical management tools in place (e.g., MLS, species catch limits or bans, 
MPA design, and revision of seasonal closures for some species), while the harvesting and stock status of a number of potentially vulnerable and/or highly exploited species by MRF (e.g., seabreams, seabass) needs to be better evaluated and properly regulated.

The MRF potential for research through the knowledge of recreational fishers (e.g., traditional ecological knowledge, citizen science) and sport fishing (Guerreiro et al. 2011) should be considered as a potential source of data to be integrated in future management strategies. The acknowledgment use and implementation of the above recommendations would result in considerable benefits to an overall MRF regulatory framework. More adequate regulations, coupled with proper participation of all the stakeholder in the management and decision-making process, and adequate enforcement would likely result in increased acceptance and compliance with the measures in place. In addition, and as suggested by Veiga et al. (2013) programs to increase fishers awareness of regulations in place, such as a code of practice for MRF (e.g., including a summary of the main regulations, main targeted species and their biology, and maps with the restriction zones), along with other education programs to explain the reasons behind the regulations and educate recreational fishers toward best practices (e.g., on minimizing bycatch, and handling and releasing fish), would likely result in better compliance and more responsible fishing practices.

\section{Funding}

CP would like to acknowledge FCT/MEC national funds and FEDER co-funding, within the PT2020 partnership Agreement and Compete 2020, for the financial support to CESAM [UID/AMB/50017/2019]. The CCMAR affiliated authors would like to acknowledge Portuguese national funds from FCT - Foundation for Science and Technology through project UIDB/04326/2020. MR would also like to acknowledge FCT funding through a post-doctoral grant (SFRH/BPD/116307/2016). AS would like to acknowledge the support of FCT through the strategic project UID/ MAR/04292/2013 granted to MARE, and also the support of the Integrated Program of SR \& TD "Smart Valorization of Endogenous Marine Biological Resources Under a Changing Climate" (reference Centro-01-0145-FEDER000018), co-funded by Centro 2020 program, Portugal 2020, European Union, through the European Regional Development Fund.

\section{ORCID}

Hugo Diogo (iD http://orcid.org/0000-0002-9269-3339

\section{References}

Abecasis D, Afonso P, Erzini K. 2015. Toward adaptive management of coastal MPAs: the influence of different conservation targets and costs on the design of no-take areas. Ecol Inform. 30:263-270. doi:10.1016/j.ecoinf.2015. 08.009

Addessi L. 1994. Human disturbance and long-term changes on a rocky intertidal community. Ecol Appl. 4(4): 786-797. doi: $10.2307 / 1942008$

Aleixo A. 2013. Pesca lúdica e apanha do casulo na Ria de Aveiro: 2012/2013 [MS thesis]. Aveiro (Portugal): Universidade de Aveiro.

Aleixo A, Queiroga H, Xenarios S, Lillebø A. 2014. Catch estimates and bioecomomic analysis of bait digging: the case of the tube worm Diopatra neapolitana. Bioforsk Rapport, 9:136. doi:10.13140/2.1.2945.7604

Arlinghaus R, Cooke SJ. 2009. Recreational fisheries: socioeconomic importance, conservation issues and management challenges. In: Dickson, B, Hutton J, Adams WA, editors. Recreational hunting, conservation and rural livelihoods: science and practice. Oxford (UK): Blackwell Publishing. p. 39-58.

Arlinghaus R, Tillner R, Bork M. 2015. Explaining participation rates in recreational fishing across industrialised countries. Fish Manag Ecol. 22(1):45-55. doi:10.1111/fme. 12075

Assis J, Gonçalves JM, Veiga P, Pita C. 2018. Spearfishing in Portugal: a baseline study on spearfishers' profiles, habits and perceptions towards management measures. Fish Manag Ecol. 25(6):417-428. doi:10.1111/fme.12313

Batista MI, Cabral HN. 2016. An overview of marine protected areas in SW Europe: factors contributing to their management effectiveness. Ocean Coast Manage. 132: 15-23. doi:10.1016/j.ocecoaman.2016.07.005

Bicho N, Haws J. 2008. At the land's end: marine resources and the importance of fluctuations in the coastline in the prehistoric hunter-gatherer economy of Portugal. Quat Sci Rev. 27(23-24):2166-2175. doi:10.1016/j.quascirev. 2008.08.011

Boaventura D, Re P, Cancela da Fonseca L, Hawkins SJ. 2002. Intertidal rocky shore communities of the continental Portuguese coast: analysis of distribution patterns. Mar Ecol. 23(1):69-90. doi:10.1046/j.1439-0485.2002. 02758.x

Briggs JC. 1974. Marine zoogeography. New York (NY): McGraw-Hill Book C.O.

Brownscombe JW, Bower SD, Bowden W, Nowell L, Midwood JD, Johnson N, Cooke SJ. 2014. Canadian recreational fisheries: 35 years of social, biological, and economic dynamics from a national survey. Fisheries. 39(6): 251-260. doi:10.1080/03632415.2014.915811

Carvalho AN, Vaz ASL, Sérgio TIB, Santos PJ. 2013 Sustainability of bait fishing harvesting in estuarine ecosystems-case study in the Local Natural Reserve of Douro Estuary. Rev Gestão Costeira Integr. 13(2): 157-168. doi:10.5894/rgci393

Carvalho S, Constantino R, Cerqueira M, Pereira F, Subida MD, Drake P, Gaspar MB. 2013. Short-term impact of bait digging on intertidal macrobenthic assemblages of two south Iberian Atlantic systems. Estuar Coast Shelf Sci.132:65-76. doi:10.1016/j.ecss.2011.06.017 
Castro JJRDP. 2004. Predação Humana No Litoral Alentejano: caracterização, Impacte Ecológico e Conservação [PhD thesis]. Évora (Portugal): Universidade de Évora.

Cheung WW, Watson R, Morato T, Pitcher TJ, Pauly D. 2007. Intrinsic vulnerability in the global fish catch. Mar Ecol Prog Ser. 333:1-12. doi:10.3354/meps333001

Cisneros-Montemayor AM, Sumaila UR. 2010. A global estimate of benefits from ecosystem-based marine recreation: potential impacts and implications for management. J Bioecon. 12(3):245-268. doi:10.1007/s10818-0109092-7

Constantino R, Gaspar MB, Pereira F, Carvalho S, Cúrdia J, Matias D, Monteiro CC. 2009. Environmental impact of razor clam harvesting using salt in Ria Formosa lagoon (Southern Portugal) and subsequent recovery of associated benthic communities. Aquatic Conserv Mar Freshw Ecosyst. 19(5):542-553. doi:10.1002/aqc.995

Cooke SJ, Cowx IG. 2004. The role of recreational fishing in global fish crises. Bioscience. 54(9):857-859. doi:10. 1641/0006-3568(2004)054[0857:TRORFI]2.0.CO;2

Costa AB. 2012. Fishing on Alentejo rocky shores-intensity, yield and protection effects [MS thesis]. Sines (Portugal): Universidade de Évora.

Costa JL, Clode J, Castro CJ, Cancela da Fonseca L, Chainho P, Fidalgo e Costa P, Sá E, Alves AS, Castro N, Cabral S, Mirra C. 2015. Estudo sobre a caracterização da apanha de isco nos principais sistemas estuarinos nacionais e caracterização da atividade de importação de isco vivo. Relatório final do Projeto PROMAR "ISCO VIVO": Anelídeos poliquetas como isco vivo em Portugal: Gestão da apanha, importação e cultivo. Instituto Politécnico de Leiria, Peniche, Portugal.

Cravo A, Pereira C, Gomes T, Cardoso C, Serafim A, Almeida Rocha CT, Lopes B, Company R, Medeiros A, et al. 2012. A multibiomarker approach in the clam Ruditapes decussatus to assess the impact of pollution in the Ria Formosa lagoon, South Coast of Portugal. Mar Environ Res. 75:23-34. doi:10.1016/j.marenvres.2011.09. 012

Cruz T, Jacinto D, Sousa A, Penteado N, Pereira D, Fernandes JN, Silva T, Castro JJ. 2015. The state of the fishery, conservation and management of the stalked barnacle Pollicipes pollicipes in Portugal. Mar Environ Res. 112(Pt B):73-80. doi:10.1016/j.marenvres.2015.10.005

Cunha T, Hall A, Queiroga H. 2005. Estimation of the Diopatra neapolitana annual harvest resulting from digging activity in Canal de Mira, Ria de Aveiro. Fish Res. 76(1):56-66. doi:10.1016/j.fishres.2005.05.008

Deville P, Linard C, Martin S, Gilbert M, Stevens FR, Gaughan AE, Blondel VD, Tatem AJ. 2014. Dynamic population mapping using mobile phone data. Proc Natl Acad Sci USA. 111(45):15888-15893. doi:10.1073/pnas. 1408439111

DGRM. 2016. Análise dos resultados do inquérito sobre a pesca lúdica 2015 Lisboa, Portugal. [accessed 12 June 2018]. https://acessoreservado.dgrm.mm.gov.pt/xportal/ xmain?xpid=dgrm\&selectedmenu=1469973\&xpgid $=$ genericPageV2\&conteudoDetalhe_v2=3435302.

DGRM. 2017. Recreational Fishing licences statistics: years 2007-2015, Direcção Geral de Recursos Naturais, Segurança e Serviços Marítimos (DGRM), [Accessed 12
June 2018] 2017. https://www.dgrm.mm.gov.pt/web/ guest/pesca-ludica?inheritRedirect=true.

Dias MP, Peste F, Granadeiro JP, Palmeirim JM. 2008. Does traditional shellfishing affect foraging by waders? The case of the Tagus estuary (Portugal). Acta Oecol. 33(2): 188-196. doi:10.1016/j.actao.2007.10.005

Diogo HMC. 2003. Contribuição Para a Caracterização da Actividade da Caça Submarina na Ilha de São Miguel, Açores [BC thesis]. Horta (Portugal): Universidade dos Açores.

Diogo HMC. 2007. Contribution to the characterisation of recreational fishing activities on the Islands of Faial and Pico, Azores [MS thesis]. Horta (Portugal): Universidade Dos Açores.

Diogo HMC, Pereira JG. 2013a. Recreational boat fishing pressure on fish communities of the shelf and shelf break of Faial and Pico Islands (Azores Archipelago): implications for coastal resource management. Acta Icth Piscat. 43(4):267-276. doi:10.3750/AIP2013.43.4.02

Diogo HMC, Pereira JG. 2013b. Impact evaluation of spear fishing on fish communities in an urban area of São Miguel Island (Azores Archipelago). Fish Manag Ecol. 20(6):473-483. doi:10.1111/fme.12036

Diogo HMC, Pereira JG. 2014. Assessing the potential biological implications of recreational inshore fisheries on sub-tidal fish communities of Azores (north-east Atlantic Ocean) using catch and effort data. J Fish Biol. 84(4): 952-970. doi:10.1111/jfb.12336

Diogo HMC, Pereira JG. 2016. Fishing in the dark: the importance of integrating a nocturnal component into recreational fishing surveys. Mar Ecol Prog Ser. 542: 187-193. doi:10.3354/meps 11520

Diogo HMC, Pereira JG, Schmiing M. 2016. Catch me if you can: non-compliance of limpet protection in the Azores. Mar Policy. 63:92-99. doi:10.1016/j.marpol.2015. 10.007

Diogo HMC, Pereira JG, Schmiing M. 2017. Experience counts: integrating spearfishers' skills and knowledge in the evaluation of biological and ecological impacts. Fish Manag Ecol. 24(2):95-102. doi:10.1111/fme.12206

Dulvy NK, Mitchell RE, Watson D, Sweeting CJ, Polunin NVC. 2002. Scale-dependent control of motile epifaunal community structure along a coral reef fishing gradient. J Exp Mar Biol Ecol. 278(1):1-29. doi:10.1016/S00220981(02)00327-1

Fernández CG, Paulo D, Serrão EA, Engelen AH. 2016. Limited differences in fish and benthic communities and possible cascading effects inside and outside a protected marine area in Sagres (SW Portugal). Mar Environ Res. 114:12-23. doi:10.1016/j.marenvres.2015.12.003

Ferreira A, Seixas S, Rijo A, Faria S, Fialho V. 2013. Impact of harvest by humans on mussel populations around Easter. Rev Gestão Costeira Integr. 13(2):145-155. doi:10. 5894/rgci383

Ferter K, Weltersbach MS, Strehlow HV, Vølstad JH, Alós J, Arlinghaus R, Armstrong M, Dorow M, de Graaf M, van der Hammen T, et al. 2013. Unexpectedly high catch-and-release rates in European marine recreational fisheries: implications for science and management. ICES J Mar Sci. 70(7):1319-1329. doi:10.1093/icesjms/fst104

Font T, Lloret J. 2014. Biological and ecological impacts derived from recreational fishing in Mediterranean 
coastal areas. Rev Fish Sci Aquac. 22(1):73-85. doi:10. 1080/10641262.2013.823907

Freire KMF, Tubino RA, Monteiro-Neto C, AndradeTubino MF, Belruss CG, Tomás ARG, PMG, Castro LS, Maruyama AC, Catella DV, Crepaldi, et al. 2016. Brazilian recreational fisheries: current status, challenges and future direction. Fish Manag Ecol. 23(3-4):276-290. doi:10.1111/fme.12171

Froese R, Pauly D. 2019. FishBase. Worldwide web electronic publication. [accessed 15 February of 2019] https:// www.fishbase.de/home.htm.

Gaspar MB, Chícharo LM, Vasconcelos P, García A, Santos AR, Monteiro CC. 2002. Depth segregation phenomenon in Donax trunculus (Bivalvia: Donacidae) populations of the Algarve coast (southern Portugal). Sci Mar. 66(2): 111-121. doi:10.3989/scimar.2002.66n2111

Gomes MC, Serrao E, Borges MF. 2001. Spatial patterns of groundfish assemblages on the continental shelf of Portugal. ICES J Mar Sci. 58(3):633-647. doi:10.1006/ jmsc.2001.1052

Gordoa A, Dedeu AL, Boada J. 2019. Recreational fishing in Spain: first national estimates of fisher population size, fishing activity and fisher social profile. Fish Res. 211: 1-12. doi:10.1016/j.fishres.2018.10.026

Guerreiro AI, Veiga P, Erzini K. 2011. Catches of the sport fishing competitions along the Algarve coast (Portugal): species, sizes, catch rates, and trends. Acta Icth Piscat. 41(3):165-169. doi:10.3750/AIP2011.41.3.03

Gupta N, Bower SD, Raghavan R, Danylchuk AJ, Cooke SJ. 2015. Status of recreational fisheries in India: development, issues, and opportunities. Rev Fish Sci Aquac. 23(3):291-301. doi:10.1080/23308249.2015.1052366

Hauck M, Sowman M, Russell E, Clark CM, Harris JM, Venter A, Beaumont J, Maseko Z. 2002. Perceptions of subsistence and informal fishers in South Africa regarding the management of living marine resources. S Afr J Mar Sci. 24(1):463-474. doi:10.2989/025776102784528556

Henry GW, Lyle JM. 2003. The national recreational and indigenous fishing survey. Orange (NSW): NSW Department of Primary Industries

Horta e Costa B, Assis J, Franco G, Erzini K, Henriques M, Gonçalves EJ, Caselle JE. 2014. Tropicalization of fish assemblages in temperate biogeographic transition zones. Mar Ecol Prog Ser. 504:241-252. doi:10.3354/meps10749

Horta e Costa B, Claudet J, Franco G, Erzini K, Caro A, Gonçalves EJ. 2016. A regulation-based classification system for Marine Protected Areas (MPAs). Mar Policy. 72: 192-198. doi:10.1016/j.marpol.2016.06.021

Hyder K, Weltersbach MS, Armstrong M, Ferter K, Townhill B, Ahvonen A, Arlinghaus R, Baikov A, Bellanger M, Birzaks J, et al. 2017. Recreational sea fishing in Europe in a global context-participation rates, fishing effort, expenditure, and implications for monitoring and assessment. Fish Fish. 19(2):225-243. doi:10. $1111 /$ faf. 12251

ICES. 2010. Report of the planning group on recreational fisheries (PGRFS). ICES CM 2010/ACOM:34.

ICES. 2018. Report of the working group on the biology and assessment of deep-sea fisheries resources (WGDEEP). ICES CM 2018/ACOM: 14.

Inglês MCG. 2010. Avaliação Dos Impactes Das Condicionantes Nas Atividades Sócioeconómicas em
Áreas Marinhas Protegidas: Caso de Estudo na Reserva Natural da Berlenga [MS thesis]. Lisboa (Portugal): Universidade de Lisboa.

IUCN. 2018. The IUCN red list of threatened species. Version 2018-2. [accessed date 2 April of 2018] http:// www.iucnredlist.org.

Leitão F, Baptista V, Zeller D, Erzini K. 2014. Reconstructed catches and trends for mainland Portugal fisheries between 1938 and 2009: implications for sustainability, domestic fish supply and imports. Fish Res. 155:33-50. doi:10.1016/j.fishres.2014.02.012

Leitão FMS, Gaspar MB. 2007. Immediate effect of intertidal non-mechanised cockle harvesting on macrobenthic communities: a comparative study. Sci Mar. 71:723-733.

Lima DR. 2006. Caracterização da Pesca Recreativa de Alto Mar, a Região Norte de Portugal [BC thesis]. Leiria (Portugal): Instituto Politécnico de Leiria

Lindfield SJ, McIlwain JL, Harvey ES. 2014. Depth refuge and the impacts of SCUBA spearfishing on coral reef fishes. PLoS One. 9(3):e92628. doi:10.1371/journal.pone. 0092628

Lloret J, Font T. 2013. A comparative analysis between recreational and artisanal fisheries in a Mediterranean coastal area. Fish Manag Ecol. 20(2-3):148-160. doi:10. 1111/j.1365-2400.2012.00868.x

Lloret J, Garrote A, Balasch N, Font T. 2014. Estimating recreational fishing tackle loss in Mediterranean coastal areas: potential impacts on wildlife. Aquat Ecosyst Health Manage. 17(2):179-185. doi:10.1080/14634988.2014 910070

Lloret J, Zaragoza N, Caballero D, Font T, Casadevall M, Riera V. 2008. Spearfishing pressure on fish communities in rocky coastal habitats in a Mediterranean Marine Protected Area. Fish Res. 94(1):84-91. doi:10.1016/j.fishres.2008.07.002

Marcelino A. 2010. Contribuição Para o Estudo da Pesca de Lazer na Península de Peniche Portugal [MS thesis]. Horta (Portugal): Universidade dos Açores.

McPhee DP, Leadbitter D, Skilleter GA. 2002. Swallowing the bait: is recreational fishing ecologically sustainable? Pac Conserv Biol. 8(1):40-51. doi:10.1071/PC020040

Menezes GM, Diogo H, Giacomello E. 2013. Reconstruction of demersal fisheries history on the Condor seamount, Azores archipelago (Northeast Atlantic). Deep Sea Res II. 98:190-203. doi:10.1016/j.dsr2.2013.02.031

Meyer CG. 2007. The impacts of spear and other recreational fishers on a small permanent Marine Protected Area and adjacent pulse fished area. Fish Res. 84(3): 301-307. doi:10.1016/j.fishres.2006.11.004

Micael J, Sonsona R, Costa AC. 2016. The potential of marine live-bait introductions into oceanic islands. J Coast Conserv. 20(2):157-164. doi:10.1007/s11852-016-0426-Z

Morales-Nin B, Moranta J, García C, Tugores MP, Grau AM, Riera F, Cerda M. 2005. The recreational fishery off Majorca Island (western Mediterranean): some implications for coastal resource management. ICES J Mar Sci. 62(4):727-739. doi:10.1016/j.icesjms.2005.01.022

National Research Council. 2006. Review of recreational fisheries survey methods. Washington (DC): National Academy Press. 
Nemoz M, Cadi A, Thienpont S. 2004. Effects of recreational fishing on survival in an Emys orbicularis population. Biologia. 59:185-189.

Oliveira MR. 2003. Contribuição Para o Estudo da Pesca Recreativa de Costa em Portugal [MS thesis]. Porto (Portugal): Universidade do Porto.

Pauly D, Zeller D. 2016. Catch reconstructions reveal that global marine fisheries catches are higher than reported and declining. Nat Commun. 7:10244. doi:10.1038/ ncomms 10244

Pawson MG, Glenn H, Padda G. 2008. The definition of marine recreational fishing in Europe. Mar Policy. 32(3): 339-350. doi:10.1016/j.marpol.2007.07.001

Pedro HC. 2017. Caracterização da Zona Entre-Marés da Reserva Mundial de Surf da Ericeira-Padrões Gerais e Pressões Humanas [MS thesis]. Lisboa (Portugal): Universidade de Lisboa.

Pereira TJ, Manique J, Quintella BR, Castro N, de Almeida PR, Costa JL. 2017. Changes in fish assemblage structure after implementation of Marine Protected Areas in the south western coast of Portugal. Ocean Coast Manage. 135:103-112. doi:10.1016/j.ocecoaman.2016.11.017

Pham CK, Canha A, Diogo H, Pereira JG, Prieto R, Morato T. 2013. Total marine fishery catch for the Azores (1950-2010. ICES J Mar Sci. 70(3):564-577. doi:10.1093/ icesjms/fst024

Pinho M, Diogo H, Carvalho J, Pereira JG. 2014. Harvesting juveniles of blackspot sea bream (Pagellus bogaraveo) in the Azores (Northeast Atlantic): biological implications, management, and life cycle considerations. ICES J Mar Sci. 71(9):2448-2456. doi:10.1093/icesjms/fsu089

Pita C, Pierce GJ, Theodossiou I, Macpherson K. 2011. An overview of commercial fishers' attitudes towards marine protected areas. Hydrobiologia. 670(1):289-306. doi:10. 1007/s10750-011-0665-9

Pita C, Theodossiou I, Pierce GJ. 2013. The perceptions of Scottish inshore fishers about marine protected areas. Mar Policy. 37:254-263. doi:10.1016/j.marpol.2012.05.007

Pita P, Artetxe I, Diogo H, Gomes P, Gordoa A, Hyder K, Pereira J, Pita C, Mafalda R, Garcia-Rodrigues J, et al. 2017. Research and management priorities for Atlantic marine recreational fisheries in Southern Europe. Mar Policy. 86:1-8. doi:10.1016/j.marpol.2017.08.030

Pollock KH, Hoenig JM, Jones CM, Robson DS, Greene CJ. 1997. Catch rate estimation for roving and access point surveys. N Am J Fish Manage. 17(1):11-19. doi:10.1577/ 1548-8675(1997)017<0011:CREFRA > 2.3.CO;2

Prista N, Jones CM, Costa JL, Costa MJ. 2008. Inferring fish movements from small-scale fisheries data: the case of Argyrosomus regius (Sciaenidae) in Portugal. ICES CM/ K: 19.

Radomski P, Heinrich T, Jones TS, Rivers P, Talmage P. 2006. Estimates of tackle loss for five Minnesota walleye fisheries. N Am J Fish Manage. 26(1):206-212. doi:10. 1577/M05-121.1

Rangel MO, Erzini K. 2007. An assessment of catches and harvest of recreational shore angling in the north of Portugal. Fish Manage. 14(5):343-352. doi:10.1111/j.13652400.2007.00560.x

Ribeiro J, Bentes L, Coelho R, Gonçalves JM, Lino PG, Monteiro P, Erzini K. 2006. Seasonal, tidal and diurnal changes in fish assemblages in the Ria Formosa lagoon
(Portugal). Estuar Coast Shelf Sci. 67(3):461-474. doi:10. 1016/j.ecss.2005.11.036

Rius M, Cabral HH. 2004. Human harvesting of Mytilus galloprovincialis Lamarck, 1819, on the central coast of Portugal. Sci Mar. 68(4):545-551. doi:10.3989/scimar. 2004.68n4545

Rodríguez Y, Pham CK. 2017. Marine litter on the seafloor of the Faial-Pico Passage, Azores Archipelago. Mar Pollut Bull. 116(1-2):448-453. doi:10.1016/j.marpolbul.2017.01. 018

Russel MW, Luckhurst BE, Lindeman KC. 2012. Management of spawning aggregations. In: Sadovy de Mitcheson Y, Colin PL, editors. Reef fish spawning aggregations: biology, research and management. Berlin (Germany): Springer. p. 371-404.

Sá E, Costa P. F e, da Fonseca LC, Alves AS, Castro N, dos Santos Cabral S, Chainho P, Canning-Clode J, Melo P, Pombo AM, et al. 2017. Trade of live bait in Portugal and risks of introduction of non-indigenous species associated to importation. Ocean Coast Manage. 146:121-128. doi:10.1016/j.ocecoaman.2017.06.016

Santos RS, Nash RD. 1995. Seasonal changes in a sandy beach fish assemblage at Porto Pim, Faial, Azores. Estuar Coast Shelf Sci. 41(5):579-591. doi:10.1016/0272 7714(95)90028-4

Santos SS. 2014. Análise de Uma Amostragem de Caça Submarina na Terceira, No Período de 1992 a 2012Comparação Com Dados de Pesca Artesanal [MS thesis]. Angra do Heroísmo (Portugal): Universidade dos Açores.

Schmiing M, Diogo H, Santos RS, Afonso P. 2014. Assessing hotspots within hotspots to conserve biodiversity and support fisheries management. Mar Ecol Prog Ser. 513:187-199. doi:10.3354/meps 10924

Sousa A, Jacinto D, Penteado N, Martins P, Fernandes J, Silva T, Castro JJ, Cruz T. 2013. Patterns of distribution and abundance of the stalked barnacle (Pollicipes pollicipes) in the central and southwest coast of continental Portugal. J Sea Res. 83:187-194. doi:10.1016/j.seares.2013. 04.005

Sousa P, Azevedo M, Gomes MC. 2005. Demersal assemblages off Portugal: mapping, seasonal, and temporal patterns. Fish Res. 75(1-3):120-137. doi:10.1016/j.fishres. 2005.03.012

Teixeira CM, Gamito R, Leitão F, Cabral HN, Erzini K, Costa MJ. 2014. Trends in landings of fish species potentially affected by climate change in Portuguese fisheries. Reg Environ Change. 14(2):657-669. doi:10.1007/s10113013-0524-5

Tran DSC, Langel KA, Thomas MJ, Blumstein DT. 2016. Spearfishing-induced behavioral changes of an unharvested species inside and outside a marine protected area. Curr Zool. 62(1):39-44. doi:10.1093/cz/zov006

Wynne-Jones J, Gray A, Hill L, Heinemann A. 2014. National panel survey of marine recreational fishers 2011-12: harvest estimates. Ministry for Primary Industries, Wellington, New Zealand.

Vandeperre FRM, Higgins J, Sánchez-Meca F, Maynou R, Goni P, Martín-Sosa P, Pérez-Ruzafa P, Afonso I, Bertocci R, Crec'hriou G, D'Anna, et al. 2011. Effects of no-take area size and age of marine protected areas on fisheries yields: a meta-analytical approach. Fish Fish. 12(4):412-426. doi:10.1111/j.1467-2979.2010.00401.x 
Vasconcelos P, Carvalho S, Castro M, Gaspar MB. 2008. The artisanal fishery for muricid gastropods (banded murex and purple dye murex) in the Ria Formosa lagoon (Algarve coast, southern Portugal). Sci Mar. 72:287-298.

Vasconcelos RP, Reis-Santos P, Fonseca V, Ruano M, Tanner S, Costa MJ, Cabral HN. 2009. Juvenile fish condition in estuarine nurseries along the Portuguese coast. Estuar Coast Shelf Sci. 82(1):128-138. doi:10.1016/j.ecss.2009.01.002

Veiga P, Gonçalves JM, Erzini K. 2011. Short-term hooking mortality of three marine fish species (Sparidae) caught by recreational angling in the south Portugal. Fish Res. 108(1):58-64. doi:10.1016/j.fishres.2010.11.021

Veiga P, Pita C, Leite L, Ribeiro J, Ditton RB, Gonçalves JMS, Erzini K. 2013. From a traditionally open access fishery to modern restrictions: Portuguese anglers' perceptions about newly implemented recreational fishing regulations. Mar Policy. 40:53-63. doi:10.1016/j.marpol.2012.12.037

Veiga P, Ribeiro J, Gonçalves JMS, Erzini K. 2010. Quantifying recreational shore angling catch and harvest in southern Portugal (north-east Atlantic Ocean): implications for conservation and integrated fisheries management. J Fish Biol. 76(9):2216-2237. doi:10.1111/j.10958649.2010.02665.x

Vinagre C, Cabral HN, Costa MJ. 2010. Relative importance of estuarine nurseries for species of the genus Diplodus (Sparidae) along the Portuguese coast. Estuar Coast Shelf Sci. 86(2):197-202. doi:10.1016/j.ecss.2009.11.013

Vinagre C, Ferreira T, Matos L, Costa MJ, Cabral HN. 2009. Latitudinal gradients in growth and spawning of sea bass, Dicentrarchus labrax, and their relationship with temperature and photoperiod. Estuar Coast Shelf Sci. 81(3):375-380. doi:10.1016/j.ecss.2008.11.015

Vinagre C, Narciso L, Cabral HN, Costa MJ, Rosa R. 2012. Coastal versus estuarine nursery grounds: effect of differential temperature and heat waves on juvenile seabass, Dicentrarchus labrax. Estuar Coast Shelf Sci. 109:133-137. doi:10.1016/j.ecss.2012.05.029 


\section{Appendix}

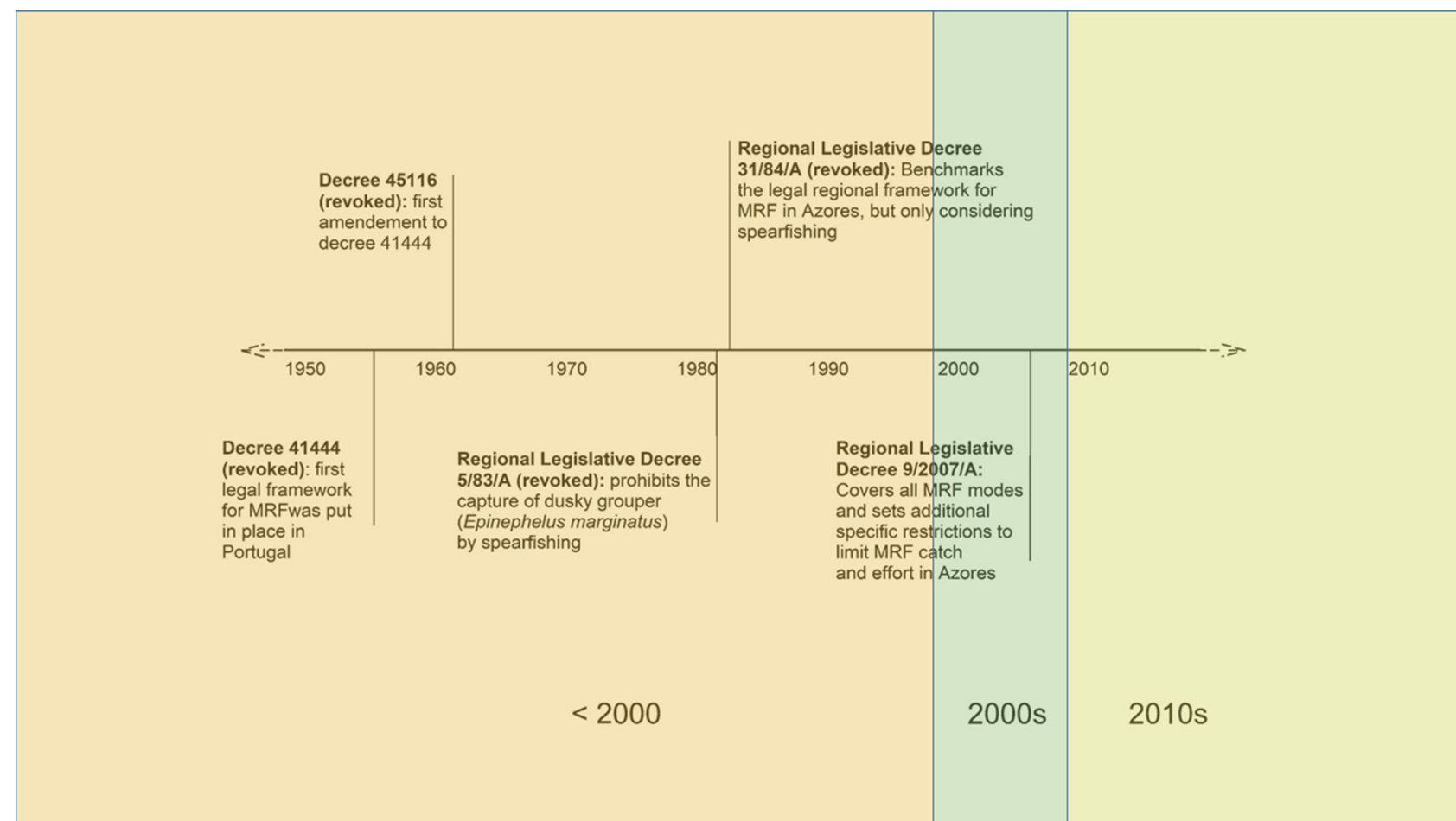

Figure A1. Regulatory history of marine recreational fishing (MRF) in the Azores archipelago. Specific regulations on MRF in MPA and technical fisheries management measures that regulate species (e.g., minimum landing sizes and seasonal closures) were not accounted.

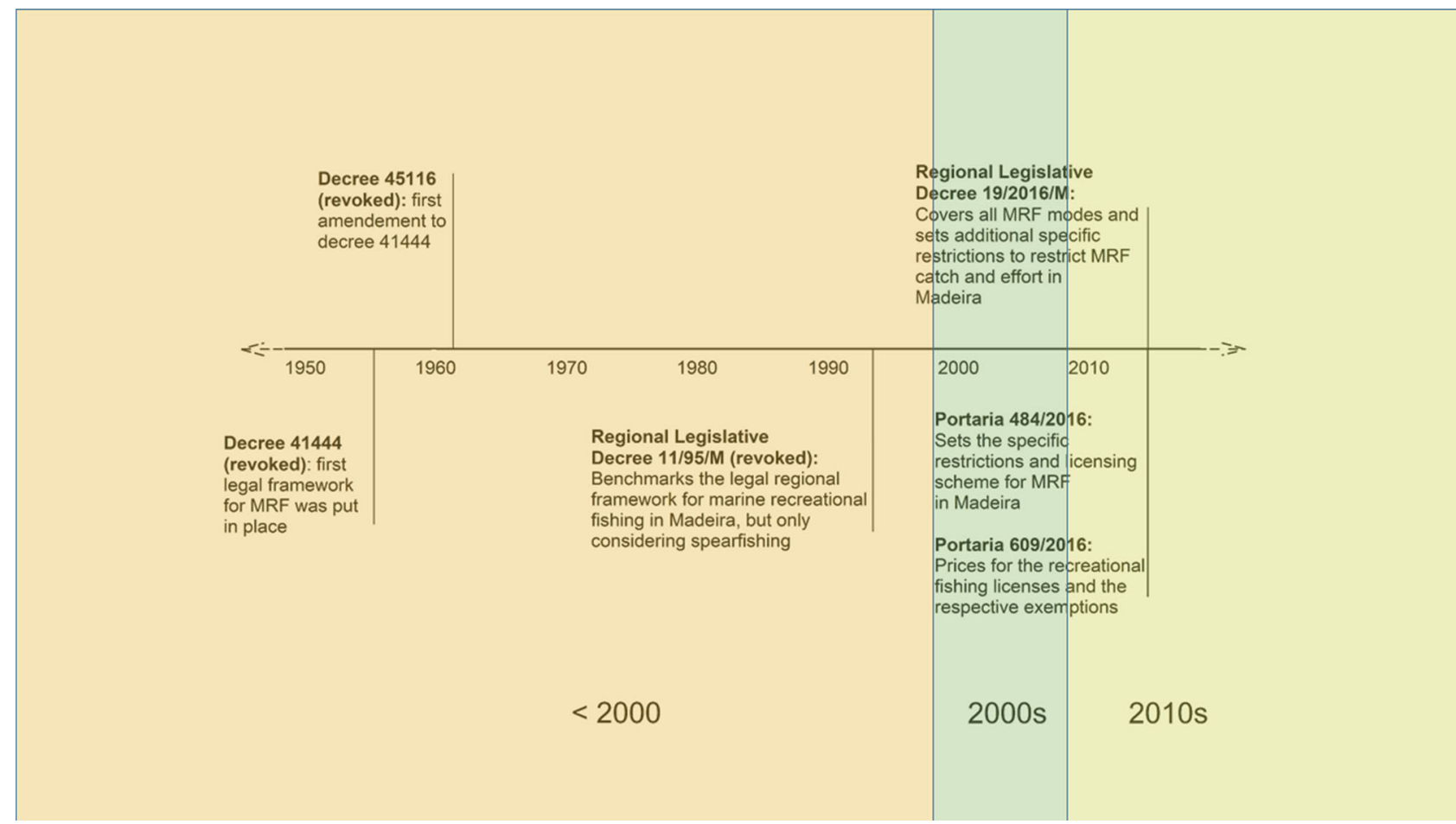

Figure A2. Regulatory history of marine recreational fishing (MRF) in the Madeira archipelago. Specific regulations on MRF in MPA and technical fisheries management measures that regulate species (e.g., minimum landing sizes and seasonal closures) were not accounted. 
Table A1. Marine recreational fisheries (MRF) management measures in force for the different main regions in Portugal.

\begin{tabular}{|c|c|}
\hline Main region & Description of MRF regulations \\
\hline Mainland Portugal & 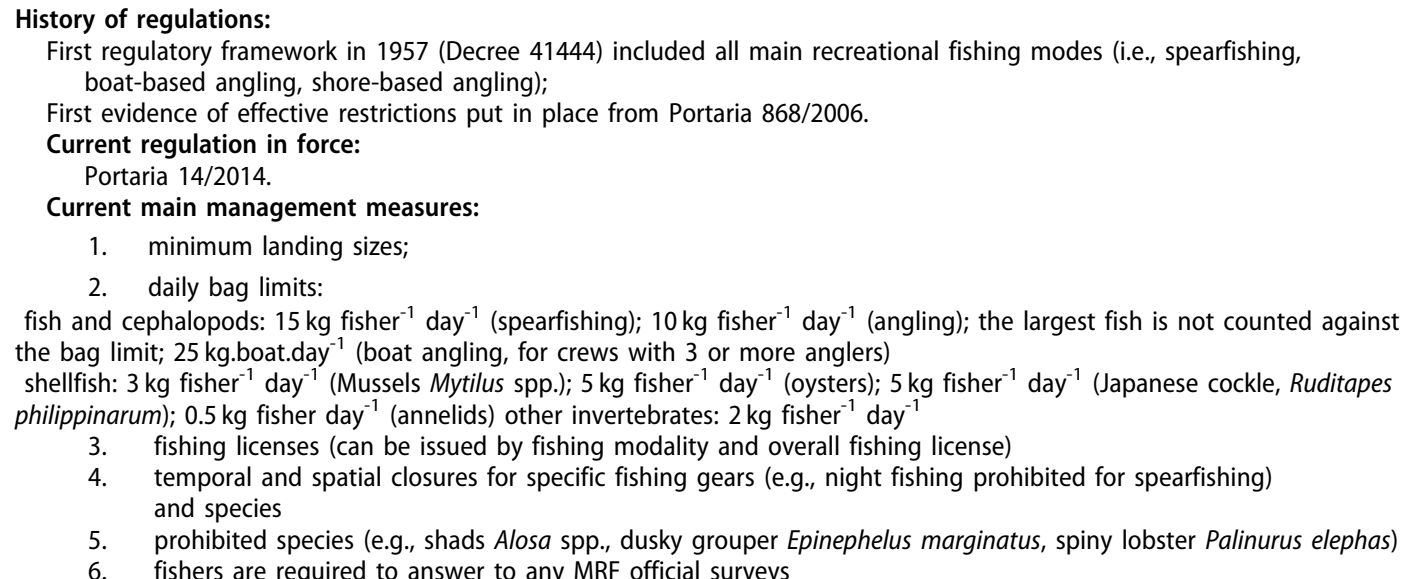 \\
\hline Azores & $\begin{array}{l}\text { History of regulations: } \\
\text { First regulatory framework in } 1957 \text { (Decree } 41444 \text { ) included all main recreational fishing modes (i.e., spearfishing, } \\
\text { boat-based angling, shore-based angling). } \\
\text { First evidence of effective restrictions put in place for spearfishing from DLR 5/1985/A } \\
\text { Current regulation in force: } \\
\text { DLR } 9 / 2007 / \mathrm{A} \\
\text { Current management measures: } \\
\text { 1. minimum landing sizes; } \\
\text { 2. daily bag limits: } \\
\text { fish and cephalopods: } 10 \text { specimens day }{ }^{-1} \text { (spearfishing); } 7.5 \mathrm{~kg} \mathrm{fisher}^{-1} \mathrm{day}^{-1} \text { for fish with less than } 40 \mathrm{~cm} \text { plus five } \\
\text { fish with more (or equal) than } 40 \mathrm{~cm}^{-1} \text { (angling); shellfish: } 1.5 \mathrm{~kg} \mathrm{fisher}^{-1} \text { day }{ }^{-1} \text { (Patella spp.) } \\
\text { 3. fishing licenses } \\
\text { temporal and spatial closures for particular gears (e.g., night fishing prohibited for spearfishing), periods, species } \\
\text { or areas } \\
\text { 5. prohibited species for spearfishing (e.g., dusky grouper Epinephelus marginatus) and bag limited of } 2 \text { specimens of } \\
\text { spiny lobster Palinurus elephas and slipper lobster Scyllarides latus } \\
\text { 6. requirement to answer to any MRF official surveys }\end{array}$ \\
\hline Madeira & $\begin{array}{l}\text { History of regulations: } \\
\text { First regulatory framework in } 1957 \text { (Decree } 41444 \text { ) included all main recreational fishing modes (i.e., spearfishing, } \\
\text { boat-based angling, shore-based angling). } \\
\text { First evidence of effective restrictions put in place from Portaria 484/2016. } \\
\text { Current regulation in force: } \\
\text { Portaria 484/2016. } \\
\text { Current management measures: } \\
\text { 1. minimum landing sizes; } \\
\text { 2. daily bag limits: } \\
\text { fish and cephalopods: } 10 \text { fish day }{ }^{-1} \text { (spearfishing); } 10 \mathrm{~kg} \mathrm{fisher}^{-1} \text { day }^{-1} \text { (angling); the two largest fish is not counted } \\
\text { against the limit shellfish: } 3 \mathrm{~kg} \mathrm{fisher}^{-1} \text { day }^{-1} \text { (Patella spp.) other invertebrates: } 2 \mathrm{~kg} \mathrm{fisher}^{-1} \text { day }^{-1} \\
\text { 3. fishing licenses } \\
\text { temporal and spatial closures for particular gears (e.g., night fishing prohibited for spearfishing), periods, species } \\
\text { or areas } \\
\text { 5. prohibited species Red List of IUCN and bag limited of } 2 \text { specimens of spiny lobster Palinurus elephas and slipper } \\
\text { lobster Scyllarides latus } \\
\text { 6. requirement to answer to any MRF related surveys }\end{array}$ \\
\hline
\end{tabular}

Table A2. Number of licenses issued annually for the Portuguese Mainland, Azores and Madeira.

\begin{tabular}{|c|c|c|c|c|c|c|c|c|c|c|c|c|}
\hline \multirow[b]{2}{*}{ Year } & \multicolumn{4}{|c|}{ Mainland Portugal } & \multicolumn{3}{|c|}{ Azores } & \multirow{2}{*}{ - } & \multicolumn{3}{|c|}{ All } & \multirow[b]{2}{*}{ Total } \\
\hline & Shore Based & $\begin{array}{c}\text { Boat } \\
\text { anglers }\end{array}$ & Spearfishing & $\begin{array}{l}\text { Combined } \\
\text { license }\end{array}$ & Spearfishing & $\begin{array}{l}\text { Boat } \\
\text { license }\end{array}$ & $\begin{array}{c}\text { Boat } \\
\text { anglers }^{\mathrm{a}}\end{array}$ & & $\begin{array}{l}\text { Shore } \\
\text { Based }\end{array}$ & $\begin{array}{c}\text { Boat } \\
\text { anglers }\end{array}$ & Spearfishing & \\
\hline 2007 & 141046 & 44619 & 15857 & n.a & n.a & n.a & n.a & n.a & 141046 & 44619 & 15857 & 201522 \\
\hline 2008 & 116884 & 39738 & 14235 & n.a & 3143 & 1282 & 2436 & 2166 & 116884 & 42174 & 19544 & 178602 \\
\hline 2009 & 112939 & 39041 & 13473 & n.a & 3217 & 1349 & 2563 & 2330 & 112939 & 41604 & 19020 & 173563 \\
\hline 2010 & 121003 & 38406 & 13165 & n.a & 3345 & 1314 & 2497 & 2725 & 121003 & 40903 & 19235 & 181141 \\
\hline 2011 & 124224 & 38393 & 12717 & n.a & 3500 & 1343 & 2552 & 2514 & 124224 & 40945 & 18731 & 183900 \\
\hline 2012 & 123095 & 37170 & 12246 & n.a & 3400 & 1404 & 2668 & 2714 & 123095 & 39838 & 18360 & 181293 \\
\hline 2013 & 116827 & 35660 & 13110 & n.a & 3278 & 1289 & 2449 & 2467 & 116827 & 38109 & 18855 & 173791 \\
\hline 2014 & 103530 & 43527 & 10247 & 2742 & 2814 & 1344 & 2554 & 2272 & 106242 & 46081 & 15333 & 167656 \\
\hline 2015 & 112467 & 64171 & 9721 & 3458 & 3014 & 1422 & 2702 & 2444 & 115904 & 66840 & 15179 & 197923 \\
\hline 2016 & 112265 & 71900 & 9718 & 3657 & 2967 & 1443 & 2742 & n.a & 115922 & 78299 & 16342 & 204692 \\
\hline
\end{tabular}

n.a - not available.

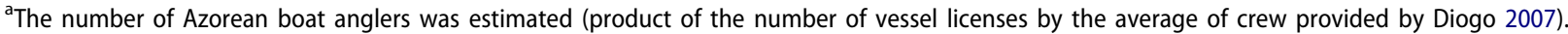


Table A3. List of captured species by shore angling identified in several on-site surveys. Sources of data - North/Center: Rangel and Erzini (2007); Center: Marcelino (2010); Algarve/Alentejo: Veiga et al. (2010); Azores: Diogo and Pereira (2014).

\begin{tabular}{|c|c|c|c|c|c|c|}
\hline Famíly & Common name & Species & North/Center & Center & Algarve/Alentejo & Azores \\
\hline Ammodytidae & Smooth sandeel & Gymnammodytes semisquamatus & $\checkmark$ & $\varnothing$ & $\varnothing$ & $\varnothing$ \\
\hline Anguillidae & Anguilla & Anguilla anguilla & $\checkmark$ & $\varnothing$ & $\varnothing$ & $\varnothing$ \\
\hline Apogonidae & Cardinal fish & Apongon imberbis & $\varnothing$ & $\varnothing$ & $\varnothing$ & $\checkmark$ \\
\hline Atherinidae & Atherina & Atherina presbyter & $\checkmark$ & $\checkmark$ & $\checkmark$ & $\varnothing$ \\
\hline Balistidae & Gray triggerfish & Balistes capriscus & $\checkmark$ & $\checkmark$ & $\checkmark$ & $\checkmark$ \\
\hline Batrachoididae & Lusitanian toadfish & Halobatrachus didactylus & $\varnothing$ & $\varnothing$ & $\checkmark$ & $\varnothing$ \\
\hline Belonidae & Garpike & Belone belone & $\checkmark$ & $\checkmark$ & $\checkmark$ & $\checkmark$ \\
\hline \multirow[t]{3}{*}{ Blennidae } & Rock goby & Gobius paganellus & $\varnothing$ & $\varnothing$ & $\varnothing$ & $\checkmark$ \\
\hline & Blenny & Lipophrys pholis & $\varnothing$ & $\varnothing$ & $\checkmark$ & $\varnothing$ \\
\hline & Red blenny & Parablennius ruber & $\varnothing$ & $\emptyset$ & $\varnothing$ & $\checkmark$ \\
\hline Bothidae & Wide-eyed flounder & Bothus podas & $\varnothing$ & $\varnothing$ & $\varnothing$ & $\checkmark$ \\
\hline \multirow{6}{*}{ Carangidae } & False scad & Caranx rhonchus & $\varnothing$ & $\varnothing$ & $\checkmark$ & $\varnothing$ \\
\hline & Atlantic horse mackerel & Trachurus trachurus & $\checkmark$ & $\checkmark$ & $\checkmark$ & $\varnothing$ \\
\hline & Blue jack mackerel & Trachurus picturatus & $\varnothing$ & $\varnothing$ & $\varnothing$ & $\checkmark$ \\
\hline & Pompano & Trachinotus ovatus & $\varnothing$ & $\varnothing$ & $\checkmark$ & $\checkmark$ \\
\hline & White trevally & Pseudocaranx dentex & $\varnothing$ & $\varnothing$ & $\varnothing$ & $\checkmark$ \\
\hline & Longfin yellowtail & Seriola rivoliana & $\varnothing$ & $\varnothing$ & $\varnothing$ & $\checkmark$ \\
\hline \multirow[t]{2}{*}{ Clupeidae } & Twaite shad & Alosa fallax & $\checkmark$ & $\varnothing$ & $\varnothing$ & $\varnothing$ \\
\hline & European pilchardus & Sardina pilchardus & $\varnothing$ & $\varnothing$ & $\varnothing$ & $\checkmark$ \\
\hline Congridae & European conger & Conger conger & $\checkmark$ & $\varnothing$ & $\varnothing$ & $\checkmark$ \\
\hline Cottidae & Longspined bullhead & Taurulus bubalis & $\checkmark$ & $\varnothing$ & $\varnothing$ & $\varnothing$ \\
\hline \multirow[t]{4}{*}{ Gadidae } & Spotted rockling & Gaidropsarus guttatus & n.i & $\varnothing$ & $\varnothing$ & $\checkmark$ \\
\hline & Pouting & Trisopterus luscus & $\checkmark$ & $\checkmark$ & $\varnothing$ & $\varnothing$ \\
\hline & Blue whiting & Micromesistius poutassou & $\checkmark$ & $\varnothing$ & $\varnothing$ & $\varnothing$ \\
\hline & Tadpole fish & Raniceps raninus & $\checkmark$ & $\varnothing$ & $\varnothing$ & $\varnothing$ \\
\hline Gobiidae & & Gobius spp. & $\varnothing$ & $\varnothing$ & $\checkmark$ & $\checkmark$ \\
\hline Kyphosidae & & Kyphosus sp. & $\varnothing$ & $\varnothing$ & $\varnothing$ & $\checkmark$ \\
\hline \multirow{8}{*}{ Labridae } & Mediterranean rainbow wrasse & Coris julis & $\checkmark$ & $\checkmark$ & $\checkmark$ & $\checkmark$ \\
\hline & Goldsinny-wrasse & Ctenolabrus rupestris & $\varnothing$ & $\varnothing$ & $\checkmark$ & $\varnothing$ \\
\hline & Ballan wrasse & Labrus bergylta & $\varnothing$ & $\checkmark$ & $\checkmark$ & $\checkmark$ \\
\hline & n.c.n & Symphodus caeruleus & $\varnothing$ & $\varnothing$ & $\varnothing$ & $\checkmark$ \\
\hline & Ornate wrasse & Thalassoma pavo & $\varnothing$ & $\varnothing$ & $\varnothing$ & $\checkmark$ \\
\hline & Axillary wrasse & Symphodus mediterraneus & $\varnothing$ & $\varnothing$ & $\varnothing$ & $\checkmark$ \\
\hline & Baillon's wrasse & Symphodus bailloni & $\varnothing$ & $\varnothing$ & $\checkmark$ & $\varnothing$ \\
\hline & Corkwing wrasse & Symphodus melops & $\varnothing$ & $\varnothing$ & $\checkmark$ & $\varnothing$ \\
\hline \multirow{2}{*}{ Moronidae } & European seabass & Dicentrarchus labrax & $\checkmark$ & $\checkmark$ & $\checkmark$ & $\varnothing$ \\
\hline & Spotted seabass & Dicentrarchus puntactus & $\checkmark$ & $\varnothing$ & $\checkmark$ & $\varnothing$ \\
\hline \multirow{2}{*}{ Mugilidae } & Thicklip gray mullet & Chelon labrosus & n.i & n.i & $\checkmark$ & $\checkmark$ \\
\hline & Golden gray mullet & Liza aurata & $\varnothing$ & $\varnothing$ & $\checkmark$ & $\varnothing$ \\
\hline Mullidae & Striped red mullet & Mullus surmuletus & $\checkmark$ & $\varnothing$ & $\checkmark$ & $\varnothing$ \\
\hline \multirow[t]{2}{*}{ Muraenidae } & Mediterranean moray & Muraena helena & $\varnothing$ & $\varnothing$ & $\varnothing$ & $\checkmark$ \\
\hline & Black moray & Muraena augusti & $\varnothing$ & $\varnothing$ & $\varnothing$ & $\checkmark$ \\
\hline \multirow[t]{2}{*}{ Phycidae } & Forkbeard & Phycis phycis & $\varnothing$ & $\checkmark$ & $\varnothing$ & $\checkmark$ \\
\hline & Great fork-beard & Phycis blennoides & $\varnothing$ & $\checkmark$ & $\varnothing$ & $\varnothing$ \\
\hline Pleuronectidae & Flounder & Platichthys flesus & $\checkmark$ & $\varnothing$ & $\varnothing$ & $\varnothing$ \\
\hline \multirow[t]{2}{*}{ Pomancentridae } & Azores chromis & Chromis limbata & $\varnothing$ & $\varnothing$ & $\varnothing$ & $\checkmark$ \\
\hline & Damselfish & Abudefduf luridus & $\varnothing$ & $\varnothing$ & $\varnothing$ & $\checkmark$ \\
\hline Pomatomidae & Bluefish & Pomatomus saltatrix & $\varnothing$ & $\varnothing$ & $\varnothing$ & $\checkmark$ \\
\hline Scombridae & Atlantic black skipjack & Euthynnus alletteratus & $\varnothing$ & $\varnothing$ & $\checkmark$ & $\varnothing$ \\
\hline & Atlantic chub mackerel & Scomber colias & $\checkmark$ & $\checkmark$ & $\checkmark$ & $\checkmark$ \\
\hline & Atlantic mackerel & Scomber scombrus & $\checkmark$ & $\checkmark$ & $\checkmark$ & $\varnothing$ \\
\hline Scophthalmidae & Turbot & Psetta maxima & $\varnothing$ & $\varnothing$ & $\checkmark$ & $\varnothing$ \\
\hline & Brill & Scophthalmus rhombus & $\checkmark$ & $\varnothing$ & $\varnothing$ & $\varnothing$ \\
\hline Scorpaenidae & Small red scorpionfish & Scorpaena notata & $\varnothing$ & $\varnothing$ & $\checkmark$ & $\varnothing$ \\
\hline & Black scorpionfish & Scorpaena porcus & $\varnothing$ & $\varnothing$ & $\checkmark$ & $\varnothing$ \\
\hline & & n.i & $\varnothing$ & $\varnothing$ & $\checkmark$ & $\checkmark$ \\
\hline Soleidae & Common sole & Solea vulgaris & $\checkmark$ & $\varnothing$ & n.i & $\varnothing$ \\
\hline Serranidae & Whiting & Merlangius merlangus & $\varnothing$ & $\checkmark$ & $\varnothing$ & $\varnothing$ \\
\hline & Comber & Serranus cabrilla & $\varnothing$ & $\checkmark$ & $\checkmark$ & $\varnothing$ \\
\hline & Blacktail comber & Serranus atricauda & $\varnothing$ & $\varnothing$ & $\varnothing$ & $\checkmark$ \\
\hline & Dusky grouper & Epinephelus marginatus & $\varnothing$ & $\varnothing$ & $\varnothing$ & $\checkmark$ \\
\hline & Mottled grouper & Mycteroperca rubra & $\checkmark$ & $\varnothing$ & $\varnothing$ & $\varnothing$ \\
\hline Scaridae & Parrotfish & Sparisoma cretense & $\varnothing$ & $\varnothing$ & $\emptyset$ & $\checkmark$ \\
\hline Sparidae & Bogue & Boops boops & $\checkmark$ & $\checkmark$ & $\checkmark$ & $\checkmark$ \\
\hline & Annular seabream & Diplodus annularis & $\checkmark$ & $\checkmark$ & $\checkmark$ & $\varnothing$ \\
\hline & Senegal sea bream & Diplodus bellottii & $\varnothing$ & $\varnothing$ & $\checkmark$ & $\varnothing$ \\
\hline & Zebra seabream & Diplodus cervinus & $\varnothing$ & $\checkmark$ & $\checkmark$ & $\varnothing$ \\
\hline & Sharpsnout seabream & Diplodus puntazzo & $\varnothing$ & $\varnothing$ & $\checkmark$ & $\varnothing$ \\
\hline & White seabream & Diplodus sargus & $\checkmark$ & $\checkmark$ & $\checkmark$ & $\checkmark$ \\
\hline & Common two-banded seabream & Diplodus vulgaris & $\checkmark$ & $\checkmark$ & $\checkmark$ & $\checkmark$ \\
\hline
\end{tabular}


Table A3. Continued.

\begin{tabular}{|c|c|c|c|c|c|c|}
\hline Famíly & Common name & Species & North/Center & Center & Algarve/Alentejo & Azores \\
\hline & Sand steenbras & Lithognathus mormyrus & $\varnothing$ & $\varnothing$ & $\checkmark$ & $\varnothing$ \\
\hline & Saddled seabream & Oblada melanura & $\varnothing$ & $\varnothing$ & $\checkmark$ & $\varnothing$ \\
\hline & Axillary seabream & Pagellus acarne & $\checkmark$ & $\emptyset$ & $\checkmark$ & $\checkmark$ \\
\hline & Blackspot seabream & Pagellus bogaraveo & $\varnothing$ & $\varnothing$ & $\checkmark$ & $\checkmark$ \\
\hline & Common Pandora & Pagellus erythrinus & $\varnothing$ & $\varnothing$ & $\checkmark$ & $\varnothing$ \\
\hline & Red porgy & Pargus pagrus & $\varnothing$ & $\checkmark$ & $\checkmark$ & $\checkmark$ \\
\hline & Salema & Sarpa salpa & $\checkmark$ & $\checkmark$ & $\checkmark$ & $\checkmark$ \\
\hline & Black seabream & Spondyliosom cantharus & $\varnothing$ & $\checkmark$ & $\varnothing$ & $\varnothing$ \\
\hline & Gilthead seabream & Sparus aurata & $\checkmark$ & $\varnothing$ & $\checkmark$ & $\varnothing$ \\
\hline Scorpaenidae & Scorpaenfishes & Scorpaena sp. & $\varnothing$ & $\varnothing$ & $\varnothing$ & $\varnothing$ \\
\hline Sphyraenidae & Yellowmouth barracuda & Sphyraena viridensis & $\varnothing$ & $\emptyset$ & $\varnothing$ & $\checkmark$ \\
\hline Synodontidae & Atlantic lizardfish & Synodus saurus & $\varnothing$ & $\varnothing$ & $\varnothing$ & $\checkmark$ \\
\hline Tetraodontidae & Guinean puffer & Sphoeroides marmoratus & $\varnothing$ & $\emptyset$ & $\varnothing$ & $\checkmark$ \\
\hline \multirow[t]{3}{*}{ Trichinidae } & Lesser weever & Echiichthys vipera & $\varnothing$ & $\emptyset$ & $\checkmark$ & $\emptyset$ \\
\hline & Greater weever & Trachinus draco & $\varnothing$ & $\varnothing$ & $\checkmark$ & $\varnothing$ \\
\hline & Weevers & Trachinus sp. & $\checkmark$ & $\checkmark$ & $\varnothing$ & $\varnothing$ \\
\hline \multirow[t]{2}{*}{ Triglidae } & Red gurnard & Chelidonichthys spp. & $\varnothing$ & $\varnothing$ & $\checkmark$ & $\varnothing$ \\
\hline & & $n . i$ & $\checkmark$ & $\varnothing$ & $\varnothing$ & $\varnothing$ \\
\hline Asteridae & Seastar & Marthasterias glacialis & $\checkmark$ & $\varnothing$ & $\varnothing$ & $\varnothing$ \\
\hline Loliginidae & Squid & Loligo vulgaris & $\checkmark$ & $\emptyset$ & $\varnothing$ & $\emptyset$ \\
\hline Octopodidae & Common octopus & Octopus vulgaris & $\varnothing$ & $\checkmark$ & $\varnothing$ & $\checkmark$ \\
\hline Portunidae & Velvet crab & Necora puber & $\checkmark$ & $\varnothing$ & $\varnothing$ & $\varnothing$ \\
\hline Total of taxa & & & 36 & 25 & 46 & 44 \\
\hline
\end{tabular}

$\checkmark$ - Species identified in the survey; $\varnothing$ - Species not identified in the survey; n.i - Taxon not identified to species level. 
Table A4. List of captured species by boat angling identified in surveys in the Azores (Diogo and Pereira 2013a) and the North of mainland Portugal (Lima 2006).

\begin{tabular}{|c|c|c|c|c|}
\hline Famíly & Common name & Species & North & Azores \\
\hline Balistidae & Gray triggerfish & Balistes capriscus & $\varnothing$ & $\checkmark$ \\
\hline \multirow[t]{2}{*}{ Berycidae } & Alfonsino & Beryx decadactylus & $\varnothing$ & $\checkmark$ \\
\hline & Splendid Alfonsino & Beryx splendens & $\varnothing$ & $\checkmark$ \\
\hline \multirow[t]{4}{*}{ Carangidae } & Atlantic horse mackerel & Trachurus trachurus & $\checkmark$ & $\varnothing$ \\
\hline & Blue jack mackerel & Trachurus picturatus & $\varnothing$ & $\checkmark$ \\
\hline & White trevally & Pseudocaranx dentex & $\varnothing$ & $\checkmark$ \\
\hline & Longfin yellowtail & Seriola rivoliana & $\varnothing$ & $\checkmark$ \\
\hline Congridae & European conger & Conger conger & $\varnothing$ & $\checkmark$ \\
\hline \multirow[t]{2}{*}{ Gadidae } & Pouting & Trisopterus luscus & $\sqrt{2}$ & $\varnothing$ \\
\hline & Poor cod & Trisopterus minutus & $\checkmark$ & $\varnothing$ \\
\hline \multirow[t]{4}{*}{ Labridae } & Barred hogfish & Bodianus scrofa & $\varnothing$ & $\checkmark$ \\
\hline & Mediterranean rainbow wrasse & Coris julis & 2 & 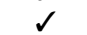 \\
\hline & Azorean blue wrasse & Centrolabrus caerulius & $\varnothing$ & $\checkmark$ \\
\hline & Ballan wrasse & Labrus bergylta & $\varnothing$ & $\checkmark$ \\
\hline Lotidae & Blue ling & Molva dypterygia & $\checkmark$ & $\varnothing$ \\
\hline Moronidae & European seabass & Dicentrarchus labrax & $\checkmark$ & $\varnothing$ \\
\hline \multirow{2}{*}{ Muraenidae } & Mediterranean moray & Muraena helena & $\varnothing$ & $\checkmark$ \\
\hline & Black moray & Muraena augusti & $\varnothing$ & $\checkmark$ \\
\hline Phycidae & Forkbeard & Phycis phycis & $\varnothing$ & $\checkmark$ \\
\hline Polyprionidae & Wreckfish & Polyprion americanus & $\varnothing$ & $\checkmark$ \\
\hline Pomancentridae & Azores chromis & Chromis limbata & $\varnothing$ & $\checkmark$ \\
\hline Rajidae & Thornback ray & Raja clavata & $\varnothing$ & $\checkmark$ \\
\hline Scaridae & Parrotfish & Sparisoma cretense & $\varnothing$ & $\checkmark$ \\
\hline \multirow[t]{2}{*}{ Scombridae } & Atlantic chub mackerel & Scomber colias & $\checkmark$ & $\checkmark$ \\
\hline & Atlantic mackerel & Scomber scombrus & $\checkmark$ & $\varnothing$ \\
\hline Sebastes & Blackbelly rosefish & Helicolenus dactylopterus & $\checkmark$ & $\checkmark$ \\
\hline \multirow[t]{2}{*}{ Scorpaenidae } & Offshore rockfish & Pontinus kuhlii & $\varnothing$ & $\checkmark$ \\
\hline & Red scorpionfish & Scorpaena scrofa & $\varnothing$ & $\checkmark$ \\
\hline \multirow[t]{3}{*}{ Serranidae } & Comber & Serranus cabrilla & $\checkmark$ & $\varnothing$ \\
\hline & Blacktail comber & Serranus atricauda & $\varnothing$ & $\checkmark$ \\
\hline & Dusky grouper & Epinephelus marginatus & $\varnothing$ & $\checkmark$ \\
\hline Scaridae & Parrotfish & Sparisoma cretense & $\varnothing$ & $\checkmark$ \\
\hline Scyliorhinidae & Lesser spotted dogfish & Scyliorhinus canicula & $\checkmark$ & $\varnothing$ \\
\hline \multirow[t]{8}{*}{ Sparidae } & Bogue & Boops boops & $\checkmark$ & $\checkmark$ \\
\hline & White seabream & Diplodus sargus & $\varnothing$ & $\checkmark$ \\
\hline & Common two-banded seabream & Diplodus vulgaris & $\checkmark$ & $\varnothing$ \\
\hline & Axillary seabream & Pagellus acarne & $\checkmark$ & $\checkmark$ \\
\hline & Blackspot seabream & Pagellus bogaraveo & $\checkmark$ & $\checkmark$ \\
\hline & Red porgy & Pargus pagrus & $\varnothing$ & $\checkmark$ \\
\hline & Gilthead seabream & Sparus aurata & $\checkmark$ & $\varnothing$ \\
\hline & Black seabream & Spondyliosoma cantharus & $\checkmark$ & $\varnothing$ \\
\hline Sphyraenidae & Yellowmouth barracuda & Sphyraena viridensis & $\varnothing$ & $\checkmark$ \\
\hline Synodontidae & Atlantic lizardfish & Synodus saurus & $\varnothing$ & $\checkmark$ \\
\hline Triglidae & Gurnards & Leptidotrigla spp. & $\checkmark$ & $\varnothing$ \\
\hline Trichiuridae & Silver scabbardfish & Lepidopus caudatus & $\varnothing$ & $\checkmark$ \\
\hline \multirow[t]{2}{*}{ Loliginidae } & European Squid & Loligo vulgaris & $\checkmark$ & $\varnothing$ \\
\hline & Veined squid & Loligo forbesii & $\varnothing$ & $\checkmark$ \\
\hline Total of taxa & & & 19 & 34 \\
\hline
\end{tabular}

$\checkmark$ - Species identified in the survey; $\varnothing-$ Species not identified in the survey. 
Table A5. List of captured species by spearfishing in Azorean surveys and reported species in off-site national assessment, namely: Azores (Diogo and Pereira 2013b) and National (Assis et al. 2018).

\begin{tabular}{|c|c|c|c|c|}
\hline Famíly & Common name & Species & Azores & National \\
\hline Balistidae & Gray triggerfish & Balistes capriscus & $\checkmark$ & $\checkmark$ \\
\hline Bothidae & Wide-eyed flounder & Bothus podas & $\checkmark$ & $\varnothing$ \\
\hline \multirow{2}{*}{ Carangidae } & White trevally & Pseudocaranx dentex & $\checkmark$ & $\checkmark$ \\
\hline & Longfin yellowtail & Seriola rivoliana & $\checkmark$ & $\checkmark$ \\
\hline Congridae & European conger & Conger conger & $\checkmark$ & $\checkmark$ \\
\hline Kyphosidae & Yellow sea chub & Kyphosus incisor & $\checkmark$ & $\varnothing$ \\
\hline \multirow[t]{7}{*}{ Labridae } & Barred hogfish & Bodianus scrofa & $\checkmark$ & $\varnothing$ \\
\hline & Mediterranean rainbow wrasse & Coris julis & $\checkmark$ & $\varnothing$ \\
\hline & n.c.n & Symphodus caerulius & $\checkmark$ & $\varnothing$ \\
\hline & Ballan wrasse & Labrus bergylta & $\checkmark$ & $\checkmark$ \\
\hline & Cuckoo wrasse & Labrus mixtus & $\varnothing$ & $\checkmark$ \\
\hline & Ornate wrasse & Thalassoma pavo & $\checkmark$ & $\varnothing$ \\
\hline & Axillary wrasse & Symphodus mediterraneus & $\checkmark$ & $\varnothing$ \\
\hline Moronidae & European seabass & Dicentrarchus labrax & $\varnothing$ & $\checkmark$ \\
\hline Mugilidae & Thicklip gray mullet & Chelon labrosus & $\checkmark$ & $\checkmark$ \\
\hline Mullidae & Striped red mullet & Mullus surmuletus & $\checkmark$ & $\checkmark$ \\
\hline \multirow[t]{2}{*}{ Muraenidae } & Mediterranean moray & Muraena helena & $\checkmark$ & $\varnothing$ \\
\hline & Black moray & Muraena augusti & $\checkmark$ & $\varnothing$ \\
\hline Phycidae & Forkbeard & Phycis phycis & $\checkmark$ & $\checkmark$ \\
\hline Pomancentridae & Azores chromis & Chromis limbata & $\checkmark$ & $\varnothing$ \\
\hline Pomatomidae & Blue fish & Pomatomus saltatrix & $\checkmark$ & $\checkmark$ \\
\hline Scaridae & Parrotfish & Sparisoma cretense & $\checkmark$ & $\checkmark$ \\
\hline Scorpaenidae & Red scorpionfish & Scorpaena scrofa & $\checkmark$ & $\checkmark$ \\
\hline \multirow[t]{4}{*}{ Serranidae } & Comber & Serranus cabrilla & $\varnothing$ & $\checkmark$ \\
\hline & Blacktail comber & Serranus atricauda & $\checkmark$ & $\checkmark$ \\
\hline & Dusky grouper & Epinephelus marginatus & $\checkmark$ & $\checkmark$ \\
\hline & Island grouper & Mycteroperca fusca & $\checkmark$ & $\checkmark$ \\
\hline Scaridae & Parrotfish & Sparisoma cretense & $\checkmark$ & $\checkmark$ \\
\hline Sciaenidae & Meager & Argyrosomus regius & $\varnothing$ & $\checkmark$ \\
\hline Scombridae & Atlantic chub mackerel & Scomber colias & $\checkmark$ & $\varnothing$ \\
\hline Soleidae & Common sole & Solea solea & $\varnothing$ & $\checkmark$ \\
\hline \multirow[t]{6}{*}{ Sparidae } & Bogue & Boops boops & $\checkmark$ & $\varnothing$ \\
\hline & White seabream & Diplodus sargus & $\checkmark$ & $\checkmark$ \\
\hline & Common two-banded seabream & Diplodus vulgaris & $\varnothing$ & $\checkmark$ \\
\hline & Red porgy & Pargus pagrus & $\varnothing$ & $\checkmark$ \\
\hline & Salema & Sarpa salpa & $\checkmark$ & $\varnothing$ \\
\hline & Gilthead seabream & Sparus aurata & $\varnothing$ & $\checkmark$ \\
\hline Sphyraenidae & Yellowmouth barracuda & Sphyraena viridensis & $\checkmark$ & $\varnothing$ \\
\hline Synodontidae & Atlantic lizardfish & Synodus saurus & $\checkmark$ & $\varnothing$ \\
\hline Nephropidae & European lobster & Homarus gammarus & $\varnothing$ & $\checkmark$ \\
\hline Majidae & Common spider crab & Maja brachydactyla & $\checkmark$ & $\varnothing$ \\
\hline Octopodidae & Common octopus & Octopus vulgaris & $\checkmark$ & $\checkmark$ \\
\hline \multirow[t]{2}{*}{ Patellidae } & Limpet & Patella aspera & $\checkmark$ & $\varnothing$ \\
\hline & Limpet & Patella candei & $\checkmark$ & $\varnothing$ \\
\hline Portunidae & Velvet crab & Necora puber & $\varnothing$ & $\checkmark$ \\
\hline Ranellidae & Triton trumpet & Charonia lampas & $\checkmark$ & $\varnothing$ \\
\hline \multirow[t]{2}{*}{ Scyllaridae } & Slipper lobster & Scyllarus arctus & $\checkmark$ & $\checkmark$ \\
\hline & Mediterranean slipper lobster & Scyllarus latus & $\varnothing$ & $\checkmark$ \\
\hline Sepidae & Cuttlefish & Sepia officinalis & $\varnothing$ & $\checkmark$ \\
\hline Toxopneustidae & Purple sea urchin & Sphaerechinus granularis & $\checkmark$ & $\varnothing$ \\
\hline Total of taxa & & & 38 & 30 \\
\hline
\end{tabular}

$\checkmark$ - Species identified in the survey; $\emptyset$ - Species not identified in the survey. 